\title{
On the Art of Fighting: \\ A Humanist Translation of Fiore dei Liberi's Flower of Battle Owned by Leonello D'Este
}

\author{
Ken Mondschein \\ Anna Maria College / Goodwin College / Massachussets historical swordmanship
}

\begin{abstract}
The author presents a study of Bibliothèque National de France MS Latin 11269, a manuscript that he argues was associated with the court of Leonello d'Este and which represents an attempt to "fix" or "canonize" a vernacular work on a practical subject in erudite Latin poetry. The author reviews the life of Fiore dei Liberi and Leonello d'Este and discusses the author's intentions in writing, how the manuscript shows clear signs of Estense associations, and examines the manuscript both in light of its codicological context and in light of humanist activity at the Estense court. He also presents the evidence for the book having been in the Estense library. Finally, he examines the place of the manuscript in the context of the later Italian tradition of fencing books. A complete concordance is presented in the appendix.
\end{abstract}

Keywords - Leonello d'Este, humanism, Fiore dei Liberi, Latin literature, Renaissance humanism, translation

\section{INTRODUCTION}

The Flower of Battle (Flos Duellatorum in Latin or Fior di Battaglia in Italian) of Fiore dei Liberi (c. 1350-before 1425) comes down to us in four manuscripts: Getty MS Ludwig XV 13; Morgan Library M.383; a copy privately held by the Pisani-Dossi family; and Bibliothèque National de France MS Latin $11269 .{ }^{1}$ Another Fiore manuscript attested in

\footnotetext{
1 The Pisani-Dossi was published by Novati as Flos duellatorum: Il Fior di battaglia di maestro Fiore dei Liberi da Premariacco, and republished by Nostini in 1982 and Rapisardi as Flos Duellatorum in armis, sine armis, equester et pedester. An edition of all three manuscripts known at the time was published by Rubboli and Cesari as Flos Duellatorum: Manuale di Arte del Combattimento del XV secolo. Malipiero has published the Getty manuscript as Il Fior di battaglia di Fiore dei Liberi da Cividale: Il Codice Ludwig XV 13 del J. Paul Getty Museum. Leoni has published a translation of the Getty as Fior di Battaglia. There are also several synthetic treatments of Fiore's work by recreationists. They include Graziano Galvani, Girlanda Roberto, and Lorenzi Enrico's Flos Duellatorum 1409-2002: La pietra miliare della scuola marziale Italiana. See also Zanutto, Fiore dei Liberi da Premariacco e i ludi e le festi marziali in Friuli nel Medio-evo. See also my Knightly Art of Battle. Transcriptions and translations of all four manuscripts also been published online, but there have as of yet been no English translations of the Paris without significant errors. Several derivative works, such as the anonymous Wien, Österreichische Nationalbibliothek Cod. 5278 and Filippo Vadi's De Arte
} 
the Estense library, MS CX, is currently unknown and presumed lost. Of these, only the subject of the present work, the Paris, has not been formally published. ${ }^{2}$

The four manuscripts are similar in content, but differ so widely in presentation and style that a critical edition would be meaningless - and, as I shall argue, the Paris manuscript changes the source material so considerably, and in a manner so consistent with it originating in the court of Leonello d'Este, Marquis of Ferrara, that we must consider it almost a separate work. BnF MS Lat 11269 is not only a unique and beautiful work of art, but a witness to the birth of an aristocratic humanist idea, a piece of official Estense propaganda, and a direct predecessor to Baldesar Castiglione's famous statement that "the principal and true profession of the courtier ought to be that of arms." 3 By recasting knightly martial arts in refined Latin, it shows the humanistic interrelation of the academic and practical — and, by extension, courtly and scientificknowledge. (One of the introductions to the Pisani-Dossi is also in Latin, albeit of a less polished literary style.)

Of course, while the Fiore manuscripts are of interest to historians of the book and intellectual historians as examples of secular manuscript art illustrating a practical subject and evidence of the importance of such learning at the courts of early fifteenth century Italy, we must not, however, discount their significance to military historians and historians of martial arts practice. Taken as a whole, this family of manuscripts are important in that they are richly illustrated records of the chivalric martial arts of fighting in armor, out of armor, on foot, and on horseback - the earliest comprehensive take on the knightly art of battle, the first to be illustrated, and the first from Italy. Of the two earlier Fechtbücher ("fight books," the technical term for this genre of material) one, Nürnberger Handschrift GNM 3227a, is a collection of notes on sword fighting in the form of a commonplace book and most likely comes from a middle-class social background; ${ }^{4}$ while the other, Royal Armouries I.33, while illustrated, shows a priest, students, and a woman named Walpurgis practicing a civilian form of fencing with swords and bucklers. Given his subject matter and method of execution, it is unsurprising that Fiore has gained a sizeable non-scholarly audience amongst historical martial arts enthusiasts, re-enactors, and other medieval recreationists who wish to reconstruct "knightly sword fighting."

The Paris manuscript thus not only gives us a significant data point for plotting the legacy of a late medieval fencing master in the Estense court, but is interesting for being

Gladiatoria Dimicandi (Biblioteca Nazionale Centrale di Roma Codex 1324) also exist, and will be discussed later.

2 See Novati, Flos duellatorum, 29-30 and associated notes on pp. 94-95, as well as my arguments later in this introduction. MS CX was small-format and had fifteen folios in two columns.

${ }^{3}$ Libro del Cortegiano, ed. Giulio Carnazzi, 72 (I, 17).

4 See my article on fencing schools in Strasbourg in the Journal of Medieval Military History (forthcoming), as well as B. Ann Tlusty, Martial Ethic in Early Modern Germany. 
an example of a back-translation from a vernacular to Latin and an ennoblement of a practical art in literary verse form. Besides this, the Paris manuscript stands out from the other manuscripts for its lavish illustrations and because, unlike the others, the figures are placed in naturalistic space by the addition of ground under their feet. All of these features point to the Paris manuscript being designed to transform Fiore's martial and literary legacy for the milieu of a humanist court.

\section{LIFE OF FIORE DEI LIBERI}

Most of what we know of Fiore's life has been gleaned from the information he gives us in the prologues to his manuscripts, with additional research conducted in the early twentieth century by Francesco Novati and Luigi Zanutto. ${ }^{5}$ In the introduction to the Getty, Fiore states that he was the son of a knight named Benedetto, lord of the town of Premariacco located in the duchy of Friuli in the diocese of the Patriarch of Aquileia. Friuli was, at the time, a contested between Hapsburgs; the Patriarch of Aquileia, who actually resided in Udine, the largest city in the region; and the Republic of Venice. The derivation of his surname is unknown, but may have originated with a Cristallo dei Liberi of Premariacco, who was elevated in rank by the Holy Roman Emperor Henry V in the twelfth century. ${ }^{6}$ Some have argued that Fiore was from the rapidly diminishing class of liberi milites descended from Imperial administrators of the region; however, the fact that the ministeriales had by and large been absorbed into the minor nobility by the fourteenth century and that the legal divisions that made them a distinct class were disappearing makes such a thesis unlikely. He was nonetheless unquestionably connected to the German cultural zone: Fiore notes in the Pisani-Dossi prologue that he studied with a master named Johannes "called Suveno," that is, from Swabia in present-day Germany. This Johannes was himself a student of Nicholas of Toblem from the diocese of Metz, which at the time was a semi-independent border town between the Holy Roman Empire and France.

Fiore tells us in the introduction to the Pisani-Dossi, which he dates to February 10, 1409 (1410 by the modern calendar) that, at the time he wrote, he had been practicing swordsmanship for fifty years. If, like other nobly born and martially inclined youth, Fiore had begun practicing at around ten years of age, then he would have been born around 1350. The fact that he indicates forty years in the Getty prologue places the composition of that manuscript ten years earlier, in about 1400 .

Fiore's childhood would have been marked by the aftereffects of the Black Death, which ravaged the region in 1348, as well as a terrible earthquake that had struck in the same year. The Hundred Years' War raged in France; during lulls in the fighting, professional mercenaries known as condottieri sought employment in the internecine wars

\footnotetext{
5 Zanutto, Fiore dei Liberi da Premariacco.

${ }^{6}$ Ibid., 15-16.
} 
of Italy. One of these conflicts was the 1381-89 Friulian civil war, which pitted the city of Udine against the Patriarch of Aquileia. Our earliest records of Fiore's life come from this period: On August 3 of 1383, he was granted permanent residency in Udine, with his guarantor one "Lord Francesco"-probably Francesco da Savorgnan, a famous condottiere and the general of the Udinese army. ${ }^{7}$ In September of that year, he was commissioned to inspect and repair the crossbows and siege engines of the Udinese arsenal. ${ }^{8}$ The following May, "Fiore the fencing master" was recorded as one of 354 citizens charged with restoring order to the countryside, him being specifically assigned to the town of Gemona. ${ }^{9}$ Fiore was clearly as adept acting as a messenger, magistrate, and peace officer as he was as a teacher of swordsmanship.

Fiore apparently enjoyed some popularity as a master of arms amongst the nobility even before this time, as is shown by half-dozen knights and squires he claims to have trained in his prologues. The earliest we can trace chronologically was Piero del Verde, a German soldier of fortune who fought a countryman of similar profession named Pierro della Corona in Perosa near Perugia sometime between 1379 and 1381.10 Though Fiore is most associated with Niccolò III d'Este, father of Leonello, who was a noted patron of scholar and to whom the Getty and Pisani-Dossi manuscripts are dedicated, and despite the fact that historians since Novati and Zanutto have placed Fiore in the d'Este court, ${ }^{11}$ it seems more likely that he was associated with the Visconti of Milan.

7 Municipal Archive of Udine, Deliber. Consilii Civit. Utini, v. VII, c.208: 1383. Die lune tertio Augusti. Utini in consilio. Magister Flor de Civitate dimicator ieceptus fuit in vicinum Terre, cum capitulis alias observatis et D. Federigus de Savorgnano fuit fideiussor, cited in Novati, note 47.

8 Municipal Archive of Udine, Deliber. Consilii Civit. Utini, v. VII, c.239: 1383. Die 30 Septembris in Consilio Terre Utini deliberatum fuit supra balistris grossis et sagitamentis magister Flor, qui fuit de Civitate Austria (sic), qui examinet et ponat ad ordinem omnia existentia in camera Comunis et eciam que babent Fraternitates, cited in Novati, note 48.

${ }_{9}$ Municipal Archive of Udine, Annales, vol. VII, c. 78: Anno 1384, ind. VII. Infrascripti sunt qui iuraverunt astare dominio Capitaneo pro bono et tranquillo statu Terre quod contra quoscumque delinquentes et excessores fiat iusticia criminalis secundum laudabiles consuetudines Terre Utini et deliberationes consiliarias maioris Consilii et Consilii Secreti: omissis: In Burgo Glemone: Magister Florius scarmitor, cited in Novati, note 49.

10 This was the time when both men were in Perugia, as determined by comparing their biographies in the prosopographical database Note biografiche di Capitani di Guerra e di Condottieri di Ventura operanti in Italia nel 1330-1550, Online < https://condottieridiventura.it/> (retrieved May 30, 2017).

11 Numerous English-language works on Estense Ferrara exist, of which the most notable are Dean, Land and Power in Late Medieval Ferrara and Gundersheimer, Ferarra: The Style of a Renaissance Depotism. Notable scholars associated with the mid-fifteenth century Estense court included Giovanni di Michele Savonarola and Guarino Veronese. For an excellent historiographical overview of intellectual trends in the evaluation of the Renaissance, see Celenza, The Lost Italian Renaissance. 
No record exists of Fiore being on Niccolò's payroll; however, the mandati accounts only begin in the mid-1420s. Furthermore, as payments to household members were not written down in the account books, Fiore might have been either very close to the Marquis or very distant. ${ }^{12}$ However, the last two students Fiore mentions in his autobiographies in the Getty and Morgan manuscripts, Giovannino da Baio and Azzo da Castelbarco, were either Milanese or fought combats sanctioned and presided over by Gian Galeazzo Visconti, Duke of Milan and also a noted patron of learning. Since Gian Galeazzo was not named duke until 1395, we can tentatively date Fiore's tutoring Giovannino and Azzo to after this date.

On the other hand, Fiore also mentions teaching Lancillotto Beccaria of Pavia, who he describes as having run six courses with sharpened lances with a "Lord Baldassaro" in Imola. While this would seem to militate against a Visconti connection, since Lancillotto fought against the Milanese and was hanged by the troops of Duke Filippo Maria Visconti in 1418, Beccharia's rupture with the Visconti did not happen until 1402, and Francesco Visconti was in fact present at the dual baptism of Lancillotto's son and nephew in $1400 . .^{13}$ That the combat predated this seems likely as his possible opponent, "Baldassaro" was perhaps Balthasar von Braunschweig-Grubenhagen, who died in about 1400 .

Fiore's most famous student was the captain Galeazzo da Mantova (Mantua), a member of the ruling Gongaza family of Mantua and a general in Visconti service, who as to fight on horseback with the French knight Jean le Meingre, called Boucicault, in Padua in 1395; the combat was aborted when Boucicault lost patience and attacked Galeazzo before the latter could mount. The two fought again with lances on horseback in 1406; Galeazzo, the victor, was fatally shot in the eye with a crossbow bolt only a month later. Fiore also mentions training Giovannino da Baggio for a combat in Pavia in 1399, which at that time was a Milanese possession and home to the Visconti library. ${ }^{14}$ The Getty and Morgan copies of The Flower of Battle may have thus been intended as diplomatic presents from the Visconti to the d'Este. Certainly, fencing-books were not unknown in northern Italy: Fiore mentioned that both he and Galeazzo da Mantova had books on fencing, and a near-contemporary fencing-book to Fiore's called Axe-Play (Le Jeu de la Hache) was possibly penned by a Milanese master in the court of the Dukes

For a full overview of the history of fencing in the Renaissance, see my article, "The Italian Schools of Fencing: Art, Science, and Pedagogy".

12 Trevor Dean, private correspondence with Greg Mele.

13 Malipiero, Il Fior di battaglia di Fiore dei Liberi, 93. On the baptism, see online <http://condottieridiventura.it/lancillotto-beccaria/> (accessed May 30, 2017); the source for this information is not cited.

14 Malipiero, Il Fior di battaglia di Fiore dei Liberi, 94-95. 
of Burgundy. ${ }^{15}$ Likewise, in addition to Fiore's, there was at least one other fencing book in the Estense library in 1436 (qv). We can only conclude that Fiore was most connected to the Visconti-which is a significant point of difference, since the Paris is most unquestionably an Estense production.

\section{LIFE OF LEONELLO D'ESTE}

The most defining features of Leonello's life were his illegitimate birth and his patronage of humanistic learning-both of which must be seen in the context of building an early modern state. If the first hindered him by casting doubt on his right to rule, the second was intended to bolster the same. ${ }^{16}$

Leonello was born on September 21, 1407, the second son of Niccolò III d'Este by his mistress, Stella de' Tolomei. His elder full brother was Ugo (b. 1405); his younger was Borso (b. 1413). Stella's noble birth accorded her sons certain privileges, and they were groomed as possible Estense successors from a young age. (By way of contrast, another illegitimate son, Meliaduse, was forced into a career in the Church, perhaps because his mother, Caterina Abaresani, was of lower birth—even though he was Leonello's elder.) However, Ugo, Niccolòs heir-apparent, was executed by their father in 1425 in circumstances reminiscent of a Greek tragedy and which have inspired poets, novelists, and composers ever since: Niccolò's first marriage, to Gigliola da Carrara, did not produce any offspring, and when she died of the plague in 1416, he married Laura (better known as Parisina) Malatesta, who was nearly two decades his junior and only one year older than Ugo. The predictable happened, and Niccolò had both his wife and son beheaded for the alleged adultery. Though Niccolò and the ill-fated Laura had several children, their only son, Alberto (b. 1421), died an infant, which left Leonello the logical choice for a successor. Niccolò's decision in this was no doubt influenced by the fact that the first Estense ruler of Ferrara, Obizzo II (1247-1293), was a bastard; the succession of illegitimate sons had occurred several times since; and that Niccolò himself was the legitimized son of Alberto d'Este and his mistress Isotta Albaresani. On the larger scale, it reflects the politics of gender in early modern Italy: A son, even illegitimate, was to be preferred over a daughter.

15 Le Jeu is Paris, Bibliothèque Nationale, MS français 1996. There exists a record of a payment of 12 livres in 1440 from Phillip the Good of Burgundy to a master Ambrose of Milan, his longtime master of the axe and sword. Since the amount was 12 livres and the salary was 40 deniers per month, Ambrose had been employed for at least six years. See Archives historiques et littéraires du Nord de la France et du Midi de la Belgique Vol. 3, p. 186. See also my "The Italian Schools of Fencing," p. 300.

16 See Bestor, "Bastardy and Legitimacy in the Formation of a Regional State in Italy: The Estense Succession." For a general overview of Leonello's life (even if a somewhat dated and superficial one), see Gardner, Dukes and Poets in Ferrara, 44-66. 
Legitimizing Leonello required both de facto recognition and de jure acquiescence from the Pope and Emperor. Niccolò's political maneuvering ensured both: In 1429, he negotiated Leonello's betrothal to Margarita, daughter of Gianfrancesco Gonzaga, ruler of Mantua. The marriage, which would take place in 1435, was an advantageous alliance for Niccolò since Gianfrancesco agreed to cancel a large monetary debt owed by the d'Este in lieu of a dowry; furthermore the marriage contract stipulated that Leonello would succeed his father and that Niccolò would have his son legitimized by the Pope, which the latter did in exchange for a cash payment. By 1434, Leonello was legally his father's co-ruler. However, Niccolò still hedged his bets: His 1435 will split the patrimony between Leonello and his eldest legitimate son Ercole (b. 1431) by his third wife, Ricciarda of Saluzzo, whom he had married in 1430, and it was only on his deathbed in 1441 that he named Leonello his sole heir while leaving 10,000 ducats each to Ercole and his other legitimate son by Ricciarda, Sigismondo (b. 1433). In 1445, Leonello sent the two boys to the court of Alfonso, King of Naples and father of Leonello's second wife, where they were safely out of the way.

Niccolò's case for Leonello's legitimacy as an heir rested on three arguments: The decree of the Pope, who was not also the head of Christendom but also to whom the House of Este paid homage for Ferrara; the will of the people; and Leonello's own excellence. ${ }^{17}$ One way of showing the third in order to win the second was a conspicuous display of virlità, which, as Bestor points out, encompassed both martial and sexual aspects. ${ }^{18}$ However, Leonello never achieved great fame as either a jouster or a soldier: He had been sent to Perugia in 1422 to receive his military education from the famous condottiere Braccio da Montone, staying there until Braccio's death in 1424. Ugo's execution was the following year, with its attendant consequences. During his reign, Leonello was better known as a diplomat and peacemaker, and his maneuvering kept Ferrara from being devoured by the larger powers of the peninsula.

As for the sexual aspect, Niccolò was careful to represent his eldest surviving bastard as virtuous, in control of his passions, and prudent-quite in contrast to his own reputation for profligacy. The elder d'Este had, by some counts, twenty-four illegitimate children and only five legitimate; as one scurrilous rhyme put it, "On this and that side of the Po, the father of all is Niccolò." While Leonello did father a bastard son, Francesco, born around 1430, and his and Margarita's only child, also named Niccolò, was born in 1438, he could never hope to match his father's accomplishments in this field. (Margarita died in 1439 and he remarried to Maria of Aragorn, illegitimate daughter of King Alfonso of Naples, in 1444; they had no children.) Learning and piety were therefore, for Leonello, far more acceptable displays of conspicuous virtue than were adventures in either the bed or battlefield. What Leonello's personal ability in the

\footnotetext{
17 Bestor, "Bastardy and Legitimacy in the Formation of a Regional State in Italy: The Estense Succession”, 572.

18 Ibid., 576.
} 
martial arts might have been can't be known, but in both the contemporary and posthumous depictions of him, his abilities as a scholar are far more prominent than those as a soldier.

In this field, he had notable success. Leonello, who was at first tutored by Guglielmo Capello and then, after 1429, by the accomplished Guarino Veronese, made Ferrara into a center of learning. He collected antiquities; reestablished the University in 1442, which rapidly became renowned throughout Europe; and was famed as a patron of art. Those he employed included such luminaries as the composer/lutenist Pietrobono; Piero della Francesca, who, according to Vasari, painted frescos of classical battles for the Marquis; the brothers Cristoforo and Lorenzo Conozi da Lendinara, who specialized in inlaid wood; Andrea Mantegna; Jacopo Bellini; and Pisanello, who, under Leonello's direction, cast medals resembling ancient coins, beginning a Renaissance fashion for such objects. Scholars and writers in his circle included the poets Basinio Basini and Francesco Ariosti; Angelo Decembrio, who commemorated Leonello's tastemaking in a long dialogue, De politia litteraria; Giovanni Aurispa, tutor of his half-brother Meliaduse; and Leon Battista Alberti, who wrote a seminal work on architecture. As a martial arts treatise couched in humanist Latin and illustrated with somewhat classical, the Paris manuscript fits well into this milieu.

Another display of learning that bears directly on the Paris manuscript is Leonello's use of a leopard impressa, or emblem. Niccolò had a taste for giving his offspring nontraditional names drawn from romances, and Leonello, of course, means "little lion"; naturally, it makes sense that he was drawn to a great cat that was itself a sort of "bastard," believed to be the illegitimate offspring of a lion and the mythical pard. The leopard was featured as a crest in the augmentation of arms Charles VII of France granted to the d'Estes in $1432 .{ }^{19}$ MS 11269 shows this symbol, as well, by changing the fighting posture previously known in Fiore's earlier manuscripts as the "bastard cross" to the "true cross," and the one known as the "true cross" to the "leopard." Interestingly, Pisanello also used a blindfolded lynx as a device on the Leonello medallion currently in the British Museum-perhaps a reference to the lynx symbol in Fiore's segno (a mnemonic diagram showing the attributes a swordsman ought to possess) and a certain inadequacy in the martial arena?

Leonello died in 1450 at the age of only 43 and was succeeded by his younger full brother Borso-passing over Francesco, who spent his life at the Burgundian court, and Leonello's own legitimate son Niccolò, "either because he was legitimate or because he was absent and a minor," as Pope Pius II marveled. ${ }^{20}$ Unlike, Leonello, Borso was not a man of learning or culture and, while he did keep the artistic propaganda machine rolling, is an unlikely commissioner or dedicatee for the Paris manuscript. Borso, who

19 See Nickel, "A Heraldic Note about the Portrait of Ladislaus, Count of Haag, by Hans Mielich," 145-47.

20 Ibid., 549. 
had no children, was in turn succeeded by Ercole, legitimate son of Niccolò III, in 1471, breaking the line of bastardy-in fact, Ercole executed Leonello's son Niccolò, his own nephew, for attempting to seize power.

\section{ABOUT THE PARIS MANUSCRIPT}

Having examined the social context, let us now turn to our object of study itself. First, why was this manuscript overlooked for so long? The first copy of Fiore's fight-book to come to light, the Pisani-Dossi example, has been known since it was published by Francesco Novati in 1902. The second, M.383, was acquired by John Pierpont Morgan in 1909 and has resided in the Morgan Library in New York from 1924. The third, MS Ludwig XV 13, was acquired by the J. Paul Getty Museum in 1983 from the collection of Peter and Irene Ludwig, who in turn, had acquired it in 1966 from a Sotheby's auction of the collection of Thomas Phillipps; the manuscript was first described by Anton von Euw and Joahim von Plotzek in their study of the Ludwig collection. ${ }^{21}$ Yet, the Paris version did not come to scholarly attention until I chanced upon it in 2008. That this copy of Fiore's work had been previously overlooked is not surprising, however: It was catalogued as Florius de arte luctandi and, unlike the other known versions, the couplets that describe the various martial techniques shown in the book are written in literary medieval Latin, not Friulian dialect. The only other instance of Latin in the Fiore manuscript tradition is the first of two prologues on folio 2 recto of the Pisani-Dossi. (It is unlikely that this page was originally detached from the Paris manuscript, since not only are the hands different, but the Latin of the Pisani-Dossi is followed immediately, in the same column, by a vernacular introduction. ${ }^{3}$ Furthermore, Novati described the Pisani-Dossi as unbound pages, ${ }^{22}$ while the Paris seems to be integral, bound work.) There was no reason to suspect any Fiore manuscript to have these characteristics; coupled with the relatively small number of researchers looking for such items in the $\mathrm{BnF}$ reading room (the entire catalogue not having been put online at that point), it is not surprising that the Paris manuscript was overlooked until I discovered it and paid to have it scanned. ${ }^{23}$

We can identify our manuscript as listed in the 1436 catalogue of Leonello d'Este's library as item 87 , "Libro uno de fai de arme fato per $\mathrm{M}^{\circ}$ Fiorio et da combatere, in membrana, coverto de una carta senza aleve" (One book on using weapons made by Master Fiore and on fighting, on parchment, covered by a page without boards). ${ }^{24}$ This item was in Latin, since the catalogue noted if works were in the vernacular and listed

\footnotetext{
${ }^{21}$ von Euw and Jvon Plotzek, Die Handschriften der Sammlung Ludwig (4 vols.).

22 Novati, Flos Duellatorum, 30

23 See my article in Arms and Armour 8, 2011.

${ }^{24}$ Cappelli, "La Biblioteca estense nella prima metà del secolo XV", 18. The library also had Vegetius and Fortino, and another, apparently Latin work on martial arts.
} 
them after the Latin books-i.e., Item 253, "Libro uno da insignare de scremia afigurado et cum lettere per vulgare in membrana compilado per $\mathrm{M}^{\circ}$ Fiore Furlano, coperto de chore roso" (one book on teaching fencing, illustrated and in the vernacular compiled by Maestro Fiore the Friulian, covered with red leather) which is perhaps the Getty. ${ }^{25}$ The 1467 catalogue likewise has it amongst the Latin books as "Liber Bellicosus vocatus Florius friuiolensis docens forma actorum diminicandi in duello litteris cursivis in membranis forma parva figuratus diversis modis in pluribus diversis cartis cum Litteris super figuris cum Aquilla alba et duobus Cimeriis pictis super prima carta chopertus montanina alba cum brochis et uno azullo. Cartarum inter scriptas et non scriptas 58. Signatus numero 84." "“Book on fighting called Fiore Friulano teaching the form of fencing actions in the duel, cursive lettering, small format, illustrated in many ways on many different pages with letters above the figures, with a white eagle and two crests depicted over the first page, covered in white sheep parchment with bosses and one clasp. The number of pages written and unwritten are 58. Marked number 84." However, owing to the ravages of time-notably some significant water damage- the manuscript looks somewhat different today.

In its present form, MS 11269 is covered in pasteboard and consists of 44 parchment folios measuring $18.8 \mathrm{~cm}$ in length by $12.5 \mathrm{~cm}$ in width, slightly reduced by rebinding. (Comparatively, the Getty is 27.9 by $20.6 \mathrm{~cm}$ and the Morgan 27.7 by 19.5 .) There are two guard-pages. The folios seem to be collected into ten-page quires. The first page is in poor condition due to water damage, with some text washed away. Examination with a Wood's lamp revealed no recoverable traces.

The full history and provenance of the manuscript are unclear. It was evidently rebound in the seventeenth century, and the guard-page bears a watermark of Dutch arms and initials "IM," signifying the master paper-maker who worked at the Puy-moyen mill for Sieur Janssen and who was active c. $1635 .{ }^{26} \mathrm{~A}$ sticker on the inner cover depicts a device of two crossed scepters and a crown over a chain of office with a Teutonic cross under them and a banner "du Cabinet de Livres de Pontchartrain," indicating that it belonged to Louis Phélypeaux, Marquis de Pontchartrain (1643-1727), who served as royal chancellor from 1699 until 1714 and who was a noted collector of art and books. The book thereafter entered the Bibliothèque du Roi. The recto side of the first folio contains "Florius de arte luctandi" written in a seventeenth-century hand, the number 312 crossed out, "ccc" and a buckle/thorn-type device, Star-of-David design with figure-8's top, left, and right, the note "Spplt 1. 674" in a modern hand, and a BN stamp.

The pages of the manuscript are ruled approximately 15.5 centimeters wide and divided into four unequal boxes: The top between 2.75 and 3 centimeters tall and containing the text, the one beneath that 7.5 and 8 centimeters tall and containing the matching

\footnotetext{
25 Ibid., 28

${ }^{26}$ Churchill, Watermarks in Paper in Holland, England, France, etc., in the XVII and XVIII Centuries and their Interconnection, III.
} 
illustration, the second text area below that again measuring between 2.75 and 3 centimeters, and the area for the final illustration measuring between 7.5 and 8 centimeters tall. While there is some use of color in the other manuscripts, the Paris example is by far the most extravagant, making lavish use of pigment in most illustrations - though some are unfinished, and the quality of the drawing itself is somewhat less than that of the Getty representation, as I will discuss below. The text itself is written in a quite beautiful bookhand that we might call a "gothico-antiqua," displaying elements of both medieval bookhands and the elegance and simplicity of emerging humanistic scripts. ${ }^{27}$ This hand is similar to that of the other manuscripts, but of higher quality. Each illustrated page (save 1 verso, which has the segno, and 44 recto, which has a single technique in the upper register and a verse identifying the author) contains two drawings in pen; colored with red, blue, and green ink wash; and illuminated with gilt garters and crowns, with the accompanying verse inscribed above. Taking into account the blank pages, the number of illustrations totals 164 . By way of comparison, the Getty contains 47 folios and 305 images, the Morgan 19 folios and 124 images, and the Pisani-Dossi 36 folios and 284 images. (MS CX was small-format and had fifteen folios in two columns. $)^{28}$

The contents are as follows (note that unless the book is unbound for examination, all descriptions of quires are preliminary):

1r: Blank

$1 \mathrm{v}$ : Segno. It is in poor condition due to water damage.

2r: Lances on horseback

3r, bottom: Sword on horseback begins

4r, bottom: Wrestling on horseback begins

6r: Defense against horseman on foot begins

$6 \mathrm{v}$, bottom: Spear on foot begins

$8 \mathrm{r}$, bottom: The technique for defending with two sticks against a spear, finishing $8 \mathrm{v}$, top.

8v, bottom: Pollaxe masters begin

10r, bottom: Sword in one hand begins (including half-sword and wrestling techniques)

12r, bottom: Sword in one hand ends

$12 \mathrm{v}$, top: Sword in two hands begins

\footnotetext{
${ }^{27}$ Derolez, The Palaeography of Gothic Manuscript Books, 176. Thanks to Christopher Celenza for his aid in putting a name to the hand.

${ }^{28}$ Novati, Flos Duellatorum, 29-30
} 
16, top: Sword in armor begins ${ }^{29}$

19r: Blank. This begins a quire.

$19 \mathrm{v}$, top: Sword in armor continues with the masters; this section may have been misplaced with the rebinding.

21r, top: Dagger against sword

21r, top: Self-defense against a dagger attack begins

22v: End of the middle quire

$25 \mathrm{v}$, bottom: End of dagger self-defense

26r, top: Sword in two hands at medium range

31r, top: More dagger disarms, continuing the theme on defense against a reverse blow with a dagger that ended on $25 \mathrm{v}$

28r, bottom: End of dagger self-defense

$38 \mathrm{v}$, top: Wrestling guards, beginning the section on wrestling

$42 \mathrm{v}$, bottom: End of wrestling

43r, top: Dagger defense, continuing the theme of defense against a thrust that ended on folio $28 \mathrm{r}$

44r: Final dagger defense. The bottom panel bears this legend identifying the author:

Florius hunc librum quondam peritissimus autor

Edidit • est igitur sibi plurima laudis honestas

Contribuenda viro furlana gente perfecto

$44 \mathrm{v}:$ A BN stamp and the following device:

$\mathrm{R}$

L R

I

29 Note that the armor is not depicted, but the techniques depicted belong to the sections on armored combat in the other MSS. 
The identification of the Paris manuscript as Fiore's work is beyond a reasonable doubt: Even if the author's identity were not given in the final verse on folio 44 verso, upon examination the combative system itself is instantly revealed to be his, for there is clear repetition of techniques and terminology such as the "woman's guard," even if the elaborate costumes worn by the armored combatants are somewhat different and the Latin verses are not direct translations of the vernacular poesy found in the other copies The content of the Paris example - the martial techniques described — is all to be found in the other manuscripts. None of the four manuscripts contain all 319 of Fiore's martial techniques (see appendix), which may derive from a yet-unknown master copy or may represent varying manuscripts, complicating the idea of an ur-text and making a stemma impossible. The ordering of these techniques is similar to that of the Morgan manuscript, but of course, the Morgan is incomplete. Like the Morgan, the Paris begins with lances on horseback - the longest-range, most formal form of combat-before progressing to spears on foot, poleaxes, swords, wrestling, and finally, techniques for an unarmed man to use against an attack with a dagger-the least formal form of a fight, and the closest-range.

The Paris also has fewer techniques with the two-handed sword, especially the longrange ones, while much of the sword in one hand and armored curriculum is preserved. Not all of these alterations were by design: The re-ordering of sections probably happened at the time of the re-binding, and of course 14 pages were lost when the book became damaged. Further digressions from the model will be discussed below.

\section{IV.1. Contents of the Manuscript}

The method of depicting fencing actions in time, though not explained in the Paris, is similar to the other three manuscripts: Much as artists' apprentices copied their masters' works or would-be humanists copied the letters of Cicero (the Paduan humanist Gasparino Barzizza [1360-1431] even compared learning to write literature to learning to paint from following a master's model),,$^{30}$ Fiore's fencing students emulated patterns - sequences of actions, or plays, to serve as exemplars - that were intended to work the correct techniques and tactical responses into their muscle memory.

A complex hierarchy of figures wearing crowns, garters, and both crowns and garters denotes techniques, counter-techniques, and counters to the counters: Each section begins with "masters," marked with crowns, showing positions (poste, carried over into the Latin as postae) and guards (guardie in Italian, custodiae in Latin). The guards are the "ready stances" from where one can begin a fencing or wrestling action, while Fiore's term poste can describe both guards and the positions through which one moves when performing the techniques in a sequence of actions. (I have translated each contextually, or supplied the word "guard" where clarity required it.) Each series of defensive and

\footnotetext{
30 Gasparini Barzizii Bergomatis et Guiniforti Filii Opera, ed. J. Furiettus, 1:180. See Baxandall, "Guarino, Pisanello, and Manuel Chrysoloras."
} 
offensive actions begins with a crowned master showing a defense to a particular type of attack; in the following, "students," marked with gilt garters around their legs, then step into the master's place to show possible offensive actions that can follow the defense. Finally, a "counter-master" marked with both a crown and a garter can show a counter to the student's action.

However, the Paris does not follow the earlier divisions faithfully. Some figures are given crowns that are not present in the earlier editions. To cite one instance, the master showing coda lunga (the "long tail") from horseback on folio $3 r$, lower register, wears a crown, but so do his scholars on the following folios. Fiore's unique segno also appears on the first folio. The martial techniques described are for the most part in the other manuscripts, with some notable exceptions: for instance, the aforesaid shuffling of the names of the positions and addition of the "leopard"; some of the sword guards are different; and there is also an arm trap on folio 27 verso that does not seem to be in any of the other manuscripts. Likewise, the Paris offers different views on several techniques.

The ordering of the techniques is also interesting when compared to the other manuscripts. The Paris manuscript begins with lances on horseback-the longest-range, most formal form of combat-before progressing to spears on foot, pollaxes, swords, wrestling, and finally, techniques for an unarmed man to use against an attack with a dagger - the least formal form of a fight, and the closest-range. The Morgan, though shorter, similarly begins with equestrian combat. The Getty and Pisani-Dossi, conversely, begin at the closest range, with wrestling, before proceeding to dagger, small stick (the bastoncello, the marker of judicial or military authority), sword held in both one and two hands, armored combat, and finally equestrian combat. The necessity of unarmed self-defense in this milieu is borne up by the anecdote of Niccolò d'Este having his rival Ottobuono Terzi assassinated at a "peace meeting" in 1409. ${ }^{31}$ Both the Pisani-Dossi and Getty versions are also explicitly dedicated to Niccolò and presumably laid out as he would have desired. However, the Paris manuscript is most similar to the Pisani-Dossi in its use of verse instructions; the other two manuscripts utilize more detailed, but poetically convoluted, instructions. We can therefore regard none of the existent manuscripts as the original or master-copy-if any such ever existed.

\section{IV.2. Military Equipment in the Manuscript}

Though the elaborate flowing sleeves and capes of the surcoats worn by the figures obscures what is worn beneath, the armor and costumes seem to come from no later than the first decades of the fifteenth century. Again, the vernacular "alter prologus" of the Pisani-Dossi dates the work to 1410 and that he had been training in the martial arts

31 Dean, Land and Power in Medieval Ferrara, 25. 
for 50 years, ${ }^{32}$ while in the Morgan and Getty, he says he had been training for more than 40 years, which would seem to make them older by a decade. Besides its similarities to the Pisani-Dossi, the internal evidence would seem to date the Paris manuscript after the others, as does the epigraph referring to Fiore as deceased (quondam). However, it was not likely created very much later; certainly the elaborate surcoats and fabriccovered cuirasses rather than "white armor," the cut of the doublets and fringes on the sleeves, and the use of both chausses and braies and joined hose, all point to date within the first decades of the fifteenth century.

Other notable points regarding the clothing and military equipment in the Paris manuscript include the Italian custom of wearing a light hauberk underneath a cuirass, or at least mail sleeves pointed or sewn onto an arming doublet. The few helmets in evidence (such as on folio $5 \mathrm{r}$ upper register and $21 \mathrm{v}$ upper register) seem to be early armets similar to both the other manuscripts and the example S-18 preserved in Schloss Churburg. The combatants do not wear plate shoulder protection, nor do any make use of closed-faced helmets. Also of interest is that, unlike the other Fiore manuscripts, unarmored combatants are shown fighting and being vanquished by those in armor, including both military/dueling/tournament contexts (such as the combat with pollaxes in $9 \mathrm{v}$, lower register) and civilian/self-defense contexts (such as the counter to a dagger attack in $21 \mathrm{v}$, upper register). The armor is purely symbolic, worn by the figure executing the "winning" technique. ${ }^{33}$

The equestrian equipment, while carefully observed by the artist, is likewise primarily intended to delight the viewer. The horses wear a combination of festive caparisons and barding. Their bits seem to be either of a curb or a Pelham type, with one rein attached to a ring and one to a shank. The bridles universally lack nosebands, while the saddles are widely variant, ranging from low-pommeled and cantled riding saddles to an almost fully wraparound model (such as the one on 5r, lower register), perhaps intended for jousting: This last is replete with leg protection and would have provided a superbly stable fighting-platform but been nigh-impossible to easily mount or escape from in case of an emergency (5r, upper register).

Thus, unlike in the other manuscripts, armor and military equipment in this manuscript seems to be more ideographic than naturalistic, enhancing the luxurious aspect of the work or perhaps serving a metaphor for the effectiveness of Fiore's art. In this, it is clearly a work of the Estense court; even though the frescos of Scipio Africanus and Hannibal that Vasari says Piero della Francesca executed for Leonello in the 1440s are now lost, the battle scenes in his Legend of the True Cross series in the Basilica of San Francesco in Arezzo show a similar aesthetic, with contemporary armor in a classical setting. In a sense, though the figures are artistically "grounded" by the terrain drawn under their feet, and though they show brutally effective martial techniques, they are

\footnotetext{
32 Novati, Flos Duellatorum, 194

${ }^{33}$ For definitions of terms, see Boccia, Armi Italiane.
} 
also placed in an idealized world of chivalry, much as with the contemporary tournament book of René d'Anjou ${ }^{34}$ and the fantastic, allegorical passages of arms that would be all the rage at the Burgundian court later in the fifteenth century and in which Leonello's bastard son Francesco would participate.

\section{IV.3. Date and Authorship of the Paris Manuscript}

The date of composition is unknowable with any certainty, absent a discovery in the Estense account-books. It was certainly composed before 1436, when it appears in the catalog, and most likely after Ugo's execution and Leonello being named heir-apparent in 1425. This incidentally also gives us a terminus ante quem for Fiore's life.

It is notable that the language of the Paris manuscript is remarkably more sophisticated than in the vernacular versions. Though not remaining within the bounds of Ciceronian vocabulary and predating the humanist Poggio Bracciolini's reformation of the language and script, the verse is complex, yet completely grammatical. This was composed by a skilled Latinist. While it is impossible to identify the translator, I can offer some speculation and disqualify some possible candidates. Capello, Leonello's first tutor, is unlikely, as he dismissed chivalric romance in the 1430s. ${ }^{35}$ Others in Leonello's circle were interested in such matters: For instance, the jurist and humanist Francesco Accolti, who became a professor at Ferrara in 1444, translated the Illiad into Latin prose for Leonello; however, his arrival in the city is too late for him to have composed the Paris. Decembrio, similarly, did not come until 1438. Though the both of these men were resident in Ferrara by 1429, the writing seems to be of an earlier style from that either Leonello's tutor Guarino da Verona or Giovanni Aurispa, tutor of his half-brother Meliaduse, worked in-nor did either of these two show any interest in martial matters. ${ }^{36}$

The illustrator would be even harder to identify. While the images are very much in keeping with the style of painters patronized by Niccolò and Leonardo ranging from Pisanello to Belbello di Pavia and Antonio Alberti to a man named Sagramoro who was commissioned to paint heraldic arms and tarot-cards, it is impossible to identify any hand for certain, and no reference to a book on fencing appears in Giuseppe Campori's listings of miniaturists employed by the Estense, or in Adriano Franceschini's

34 Paris, Bibliothèque Nationale, MS français 2693.

35 See Everson, The Italian Romance Epic in the Age of Humanism, 153-54 n. 51.

${ }^{36}$ For instance, the hand is different from surviving fragments that might be Guarino's autograph or copied by a scribe that worked with him, such as Ruusbroec Institute RG88c5 (Erik Kwakkel, private correspondence with Ken Mondschein. See also https://twitter.com/erik_kwakkel/status/748444897057849344, accessed August 20, 2017), or or Beinecke, MS Marston 286. 
comprehensive tome of primary sources. ${ }^{37}$ However, there are lacunae in the archives, and in surviving documents the Estense chancellery did not always make explicit references to what books were commissioned; those he favored tended to be classical authors and French romances. ${ }^{38}$ Alternately, the book might have been a gift from someone eager to court Leonello's favor.

Certainly, MS 11269 is not as high quality as great illuminated manuscripts such as the Estense Bible: The figures were drawn by a competent artist, if not a Pisanello. Rather, they likely worked from a pattern-book — quite against the directives Decembrio puts in Leonello's mouth to work up from the nude. ${ }^{39}$ Nor did the d'Este keep artists on staff: works ranging from great fresco cycles to tarot-cards were commissioned rather promiscuously. Again, we must await discoveries in the archives.

\section{IV.4. Intent of the Paris Manuscript}

Though I speculate that at least two of the vernacular manuscripts were gifts from the Visconti to the d'Este, MS 11269 is most likely an Estense production, and most likely made in Leonello's circle as a gift for him, if not actually commissioned by him personally. This is indicated by two key pieces of internal evidence. The first is, of course, the aforementioned use of the "leopard" guard. The second is a reference to "Roland and Pulicanus" on folio 6r. ${ }^{40}$ This reference does not appear in any of the other manuscripts, but the Matter of France and the ideas of d'Este legitimacy stemming from Charlemagne were a key piece of official Estense propaganda. Furthermore, the Estense library was replete with works of French chivalric romance. ${ }^{41}$ This would, of course, culminate with Matteo Maria Boiardo's (1440-1494) Orlando Immorato and Ludovico Ariosto's (1474-1533) Orlando Furioso.

Another important change from the earlier manuscripts, and one which also underscores its link to the Pisani-Dossi, is the translator's use of the idea of fencing time, or tempo, on 14v: Sit nimis hoc tempus breve quamvis tanta probando ("This must be a short tempo, although it is worthy of many good things"). This, and the use of tempo on $19 \mathrm{v}$ of the Pisani-Dossi, are the first use of the Aristotelian idea of time as "the number of the motion with respect to the before and after" in an Italian fencing book that I am aware of and underscores the relationship between the two manuscripts. ${ }^{42}$

\footnotetext{
${ }^{37}$ Campori, Notizie dei miniatori dei Principi Estensi; Adriano Franceschini Artisti a Ferrara in età umanistica e rinascimentale: testimonianze archivistiche, pt. 1. dal 1341 al 1471.
}

38 See $i$ bid. 162-64, 172-73. The entry simply states that in 1434 "many works" were created for Leonello, but some are not specified.

39 Baxandall, "Guarino, Pisanello, and Manuel Chrysoloras", 318

40 Pulicanus is King of the Moors, mentioned by Boiardo in Orlando Immorato II, XXX, 52.

${ }^{41}$ See Everson, The Italian Romance Epic in the Age of Humanism, especially Chapter 5.

42 Physics IV.11: tempus est numerus motus secundum prius et posterius. See Mondschein, "The Medieval Experience of Time: Aristotle, Universals, and Technologies", 30-37. 
Accordingly, I have translated tempus as "tempo," the fencing concept, as opposed to the less specific "time," because clearly what is being discussed is the relative duration of an action-just as the term "tempo" is still used in fencing today in an unbroken tradition since the Renaissance. (Note that Aristotelian idea of time is seen in the German tradition as early as the record of the teachings of the enigmatic master Johannes Liechtenaeuer in Nürnberger Handschrift GNM 3227a. ${ }^{43}$ This manuscript precedes Fiore's work by at least a decade and, rather than the Italian tempo, uses the terms vor [the Aristotelian "before"] and nach [the Aristotelian "after"] to describe actions.)

Why was a book on a practical skill, the martial arts, translated into erudite Latin? And how did this fit into the developing humanistic model of education in the court of Ferrara? Certainly, both the Visconti and the d'Este gathered substantial libraries of scientific and practical arts, devotional works, and both ancient and modern literaturethe beginnings of the modern research library, and a critical development for the growing culture of the Renaissance.

For the most part, books on fencing were still rare in the early fifteenth century: Fiore mentions that other than himself, none of his students, with the exception of Galeazzo da Mantova (who had married into the Visconti family) owned books on fencing. Galeazzo, according to Fiore, held that written records were key to studying the martial arts-an opinion with which the Friulian fencing master agreed, saying in both the prefaces to the Getty and Morgan editions that without books, one could hardly remember a quarter of the subject matter. I have already mentioned Le Jeu de la Hache, the only fencing book written in French before the late sixteenth century, and likely by a Milanese master in the court of the Dukes of Burgundy. ${ }^{44}$ Besides this and Fiore's works, one additional book on fencing appears in the 1436 catalogue, Item 94: "Libro uno che trata de fati de chombatere, in carta bambaxina, coverto de una carta de piegora" (One book that treats with fighting actions, in cotton paper, covered with sheep parchment). Thus, though the genre of the fighting-book seemed to have originated amongst the literate in German-speaking lands, and though illustrated medieval-style fighting books would continue to be written in Germany through the sixteenth century - mostly by burghers - and though Fiore himself might have been influenced by his study with German masters, the enthusiasm for fencing books in medieval Italy seemed to be limited to the upper class as part of an overall strategy of literary patronage and martial accomplishment with which they distinguished themselves as separate from, and superior to, their contemporaries.

\footnotetext{
43 Germanisches Nationalmuseum, Nuremberg Handschrift 3227a

44 Paris, Bibliothèque Nationale, MS français 1996. There exists a record of a payment of 12 livres in 1440 from Phillip the Good of Burgundy to a master Ambrose of Milan, his longtime master of the axe and sword. Since the amount was 12 livres and the salary was 40 deniers per month, Ambrose had been employed for at least six years. See Archives historiques et littéraires du Nord de la France et du Midi de la Belgique Vol. 3, p. 186.
} 
Leonello especially concentrated on collecting works from antiquity, though he also had practical books on equine veterinary practice such as Lorenzo Rusio's Hippiatria (which was also translated for use of the ducal farrier). ${ }^{45}$ The greatest example of this is, of course, Alberti, whose Della pittura (1435, translated into Latin as De Pictura in 1439-41) and De Re Aedificatoria (1452) respectively applied mathematics to art and architecture. Similarly, we see with the allusion to "tempo" in the Paris and Pisani-Dossi the inklings of the application of theory to fencing, which would be expanded upon by Fillippo Vadi and reach its flowering in the sixteenth century by the architect-theorist Camillo Agrippa. ${ }^{46}$

Another clue as to the manuscript's purpose can be found in its art. As mentioned above, unlike in the other manuscripts, only the figures showing Fiore's techniques are armored in the Paris. This, together with the fact that the armor and military equipment in this manuscript are not intended as naturalistic depictions, but instead enhance the luxurious aspect of the work and perhaps serving a metaphor for the effectiveness of Fiore's art, raises the manuscript above the mud, dirt, and blood of actual combat and, as Leonello seemingly preferred, moves it into the realm of fine art. As the knightly class came under pressure both from new means of waging war and from post-Plague socioeconomic realities, there came a concordant sense of exclusivity attached to displays of martial prowess properly belonging to the upper class. Thus, the fencingbook can be seen as an article of consumption, rather than a naturalistic depiction of combat.

However, it is the rhetorical purpose of this manuscript that is the most interesting of all. Fiore does not explicitly address such basic subjects as how to parry, feint, or strike-subjects that any modern fencing master would recognize as fundamental to teaching someone how to fence. Nor does he attempt to explain an overall theory of fencing, as Camillo Agrippa would in the sixteenth century. Rather, his work, like other medieval fencing books, is intended as a memorial, a reminder of teachings that would have been given live and in person. Fiore's idea of sharing knowledge was very different from today's digital democracy: He tells us that he always taught in secret, with only a close friend or relative of the student allowed to watch-and only after being sworn to secrecy. He furthermore tells us that he fought no less than five duels with jealous masters with whom he refused to share his secrets.

This explains not only the warning accompanying the segno on the first folio of the Paris that the knowledge contained therein is not to be shared openly, but also the cryptic nature of the Pisani-Dossi and Paris manuscripts, which do not contain explicit instructions, but only caption the illustrations with taunting verses that modern fencing

\footnotetext{
45 See online < http://www.textmanuscripts.com/medieval/lorenzo-rusio-dapera-hippatria60523> (accessed August 14, 2017).

46 See Forgeng, “Owning the Art: The German Fechtbuch Tradition”, 164-75.
} 
master Richard Gradkowski has aptly described as "trash talk." 47 The Getty and Morgan, however, give in-depth instructions on how to perform the various techniques. We can speculate that Fiore first sent a more abbreviated draft of The Flower of Battle (perhaps the Morgan) to Niccolò, who then requested a more complete work-one that could explain itself to the casual reader, in keeping with the new culture of the book and a new idea of knowledge that was taking shape in Italian courts. The result was the Getty manuscript. However, we need to see the Getty as the exception: The Paris is closer to the original model, and, like the closely related Pisani-Dossi, it is in verse.

While none of the Fiore manuscripts are "how to" books-they presuppose that one already knows how to fence-they represent a stage in the development of both that important Renaissance genre, the treatise on practical arts and the development of a courtly Latin culture (in the case of the Paris manuscript). Fiore's case may thus be that of an author whose patrons were perhaps more eager to take advantage of the literary culture of the Renaissance and the new ideal of sharing information than was the author himself. Fiore ultimately went along with this plan, for, as he tells us, he had an ulterior motive in writing: He wished to be remembered after his death, that is, to set down his work for posterity.

The Florius manuscript is most likely part of this posthumous legacy, which seems to imply that the author was, in fact, deceased at the time of writing, his thoughts set down, or more accurately translated, by his disciples—not an impossible or indeed uncommon occurrence in the late medieval era, as Alain Boureau has pointed out for Thomas Aquinas. ${ }^{48}$ This curious fact speaks volumes about late-medieval ideas of writing and authorship, and the Fiore dei Liberi manuscript tradition.

What does it mean to be the "author" of something in the early fifteenth century? The verse in the Paris manuscript is not a direct translation of the vernacular, nor can it possibly "say the same thing"- though by its variance, it gives the modern reader greater insight into how the various martial arts techniques are supposed to be performed. This was not, of course, the rationale behind its creation: Writing, as Mary Carruthers explains, was an action that fixed something transient—speech, whether human or divine - to the page, making a permanent record of it, even if only as an aidememoire. ${ }^{49}$ The idea of how a somatic performance such as fencing could be the subject of a permanent record and "authorship" is not much of a leap from this; all that is required is a suitable medium. Thus, the importance of Fiore's informing us he knew how to write: The system of crowned masters, gartered scholars, and crowned and gartered counter-masters is nothing less than a grammar of fencing.

\footnotetext{
${ }^{47}$ Richard Gradkowski, private correspondence with Ken Mondschein

48 Boureau, "Peut-on parler d'auteurs scholastiques?", 267-279.

${ }^{49}$ Mary Carruthers, The Book of Memory, 8-9.
} 
This idea of "fixing" is carried to its logical end by translation into Latin: Like a notary writing vernacular court testimony into Latin, the Paris manuscript serves to elevate and formalize Fiore's work. Christopher Celenza has written of the movement in early fifteenth-century courts—and especially Leonello's efforts in Ferrara, as commemorated by Angelo Decembrio in his De politia litteraria - to create "canons" of literature and permanent libraries for the use of the learned. ${ }^{50}$ Part of this was the use of Latin—or, as Celenza says of the words Decembrio puts in Leonello's mouth, “...there was no 'vernacular' in the fifteenth century. There were, instead, 'vernaculars,' varying almost incalculably by region, possessing in the minds of many an inherent instability, and as such inappropriate for serious intellectual works. Latin, on the other hand, seemed a more appropriate medium of communication because there was, at least notionally, a standard form of the language that one could reach back to, discover, and flexibly employ in the present, at once recalling Italy's greatest days of ancient glory and pointing the way toward a new role of cultural leadership." ${ }_{11}$ The ideal library would be a Latin library.

This idea of the "canonization" of Fiore, and the idea of how a somatic performance such as martial-arts techniques could be the subject of a permanent record and "authorship" in the form of a book, is also reflected by the art of the Paris, which, rather than the energetic, high-quality drawings of the Getty, is rather more formalized, with figures appearing less individualistic and more drawn from a pattern-book-less interesting from our perspective, but arguable a higher style from its audience's. One is reminded again of Barzizza's comparison of learning to write literature to following a master's model. ${ }^{52}$ We see here the essential unity in early Renaissance thought on letters: if anything, the process of translation takes the author's intention-to provide a permanent, formal, and aesthetically pleasing record of transitory things that take place in space in time- to its logical end. So, too, are the artistic priorities primarily aesthetic, rather than naturalistic: The figure showing the position of "left window guard" on folio 13 verso would ordinarily have his face covered by his sword, but the artist omits the central part of the weapon and shows instead the figure's features.

\section{IV.5. Influence}

Fiore succeed in his goal; certainly, despite his warnings not to widely share his art, he enjoyed and has since enjoyed considerable posthumous popularity. Codex 5278 in the National Library of Austria, dating from some time after 1428, contains a number of

50 Celenza, "Creating Canons in Fifteenth-Century Ferrara: Angelo Decembrio's De Politia Litteraria 1.10." See also Baxandall, “A Dialogue on Art from the Court of Leonello d'Este: Angelo Decembrio's De Politia Litteraria Pars LXVII."

51 Ibid., 61.

52 Gasparini Barzizii Bergomatis et Guiniforti Filii Opera, ed. Furiettus, Vol. 1, 180. See also Baxandall, "Guarino, Pisanello, and Manuel Chrysoloras." 
images derived from The Flower of Battle (though no text). ${ }^{53}$ Derivative illustrations are also found in a notebook from the early sixteenth century belonging to the general Ludwig von Eyb now in the university library of Erlangen, Germany. Fiore's work most probably also inspired the later author Filippo Vadi, who gifted his manuscript sometime between 1482 and 1487 to Guidobaldo da Montefeltro, Duke of Urbino, son of the famous condotierre and patron of the arts Frederico da Montefeltro, and a famous patron in his own right. ${ }^{54}$ Vadi was apparently associated with d'Este circles $; 5$ he might also be the subject of the portrait medallion cast by the Venetian artist Giovanni Boldu in 1457 with the obverse showing a figure in antique armor holding a longsword and the words "Phillipus de Vadis de Pisis Chironem Superans (Filippo Vadi of Pisa, exceeding Chiron)," or this might be another member of his family. The centaur Chiron was Achilles' tutor in sciences and martial arts, but has led to Vadi being misidentified as a physician.

Vadi's work resembles Fiore's in many respects, including its organizational principles and symbolism, though it shows a somewhat different fencing system. The link between the two authors is additionally underscored by Vadi using the "serene leopard" for the Paris "leopard" position and substitution of a "leopard's tail" for the "archer's position." Suitably for the court of Urbino, which had no shortage of scholars such as Piero della Francesca and Francesco di Giorgio Martini who wished to show the geometrical and numerical underpinnings of reality, Vadi includes a verse introduction that presents the argument that fencing, like music, is a science, since the sword is subject to Euclidian geometry:

Geometry divides and separates

with infinite numbers and measures

that fill pages with knowledge.

The sword is under its purview

since it is useful to measure blows and steps

in order to make the science more secure,

53 This codex is as yet unstudied; see, however, Mondschein, "The Italian Schools of Fencing: Art, Science, and Pedagogy", 295-298.

54 Filippo Vadi, Liber de Arte gladiatoria dimicandi; translated by Porzio and Mele.

55 In "Cenni Storica della Famiglia Vadi" (http://www.achillemarozzo.it/it/senzacategoria/famiglia-vadi, accessed August 15, 2017), Andrea Conti of Sala d'Arme Achille Marozzo claims a Filippo Vadi (1425-1501) was governor of Reggio under first Leonello and then Borso from 1452-1470; it is unknown if this was our author or an uncle. Conti cites "Amorum libri tres e la lirica settentrionale del Quattrocento" by Matteo Maria Boiardo and "Manoscritto con alcune poesie inedite" by Simone Serdini Forestani called "Saviozzo," but provides no further bibliographical information. In Facebook conversations, he cited a descendent, Ubaldo Vadi, as his source of information. 
Fencing is born from geometry

[...]

Music adorns this subject

song and sound together in art

to make it more perfect by science,

Geometry and music together

combine their scientific virtue in the sword

to adorn the great light of Mars. ${ }^{56}$

Continuing on the idea of tempo in the Paris and Pisani-Dossi, in his version of Fiore's segno, Vadi places a pair of dividers over the head of his ideal fencer: "I am a sextant that can divide | O Fencer, heed my reasoning | since you will similarly measure time." 57 (The master-at-arms whom Castiglione documented as serving in Urbino, Pietro Monte, was also notable for his interest in natural philosophy. $)^{58}$ This proportional division of time is evident in Vadi's idea of mez?o tempo, a counterattack that interrupts the adversary's action with a smaller, quicker movement. Similar conceptions of time — and the image of the dividers — reappear in later fencing books.

The watershed moment in the larger tradition of Italian fencing books is, of course, Camillo Agrippa's work of 1553, which combines humanistic ideas about the body and knowledge with the possibilities of the printing press and geometrical illustration to create an entirely new way of explaining fencing. Agrippa firmly stands in this courtly Italian tradition of scientific-literary fighting books. His milieu, influences, and background are fully explained in my introduction to my translation of his work, Fencing: A Renaissance Treatise.

The "Florius" manuscript itself is well worthy of further dissemination as a cultural artifact and an objet d'art that highlights the importance of training in arms in the birthplace of the Renaissance. A vernacular work on a practical matter by an iterant fencing master who served at noble courts has been translated and beautified, placing it in the elevated realm of literature: The fencer and the courtier are one. Most importantly, it shows us how we cannot separate the martial self-image of the late

\footnotetext{
${ }^{56}$ Ms 1342, fol. 4r, trans. Mele and Porzio pp. 42-43: La geometria che divide eparte / Per infiniti numeri emisure / Che impie di scientia le sue carte, / La spade e sotto posta a le sue cure / Convien che si mesuri $i$ colpi e i passi / Acio che la scientia tasecure / Da geometria lo scrimir se nasce / .... / La musica ladorna esa sugetto, / Chel canto elsono senframette in larte, / Per farlo di scientia piu perfecto / La geometria e musica comparte / Le loro virtu scientifiche in la spada / Per adornare el gran lume de Marte

${ }_{57}$ Ms 1324, fol. 15r; trans. Mele and Porzio pp. 88-89: Io sono un sexto che fo partimenti / O scrimitore ascolta mia ragione / Cusi misura el tempo simelmente

58 Anglo, "The Man Who Taught Leonardo Darts: Pietro Monte and his 'Lost' Fencing Book". See also Bascetta, "Il Primo Manuale Italiano Di Lotta" and Forgeng's recent translation, Pietro Monte's Collectanea.
} 
medieval Italian nobility from that of the patron of the arts; each was equally important to asserting status in the milieu of the early Renaissance, the developing culture of humanistic letters, and the development of the Western scientific mindset.

\section{ACKNOWLEDGEMENTS}

This work is connected to my forthcoming translation from Freelance Academy Press in their Flowers of Battle series; I would like to thank Greg Mele for agreeing to this prepublication on my research on the history of the manuscript. I would like to express my enormous gratitude to Tom Leoni for helping me puzzle through the often-complicated Latin in this work. Thanks also to Libby and Sarah for keeping me sane; Karen Cook for her feedback and reading my proposals; Jeffrey Forgeng and my former "home base," the late, lamented Higgins Armory Museum in Worcester; and Arthur Kinney, Joseph Black, and the University of Massachusetts Center for Interdisciplinary Renaissance Studies in Amherst, who generously provided me with a series of Fellowships in which I transcribed and began translating this manuscript.

Parts of the introduction appeared in the journal Arms and Armour, thanks to the editors and Maney Publishing for allowing me to repeat myself.

Finally, thanks to my fencing students and the historical-fencing community at large, for their eternal patience!

\section{BIBLIOGRAPHY}

\section{VI.1. Primary Sources}

Florius de Arte Luctandi (Paris, Bibliothèque Nationale de France, MS Latin 11269).

Le Jeu de la Hache (Paris, Bibliothèque Nationale de France, MS français 1996).

Fiore dei Liberi, Fior di Battaglia, 1410 (New York, Getty Museum Ludwig, XV 13).

Fiore dei Liberi, Fior di Battaglia, c. 1400 (Los Angeles, Morgan Library, M.0383).

Filippo Vadi, Liber de Arte gladiatoria dimicandi (Roma, Biblioteca Nazionale Centrale, MS 1342).

\section{VI.2. Secondary Literature}

Anglo, Sydney, The Martial Arts of Renaissance Europe (New Haven: Yale University Press, 2001).

_ , "The Man Who Taught Leonardo Darts: Pietro Monte and his 'Lost' Fencing Book", The Antiquities Journal 69 (1983), 261-278.

Baxandall, Michael, "Guarino, Pisanello, and Manuel Chrysoloras." The Journal of the Warburg and Courtauld Institutes 28 (1965), 183-204. 
Bestor, Jane Fair, "Bastardy and Legitimacy in the Formation of a Regional State in Italy: The Estense Succession”, Comparative Studies in Society and History 38/3 (1996), 549-585.

Boccia, Leonello, Armi Italiane (Bologna: Zanichelli, 1966).

Boureau, Alain, "Peut-on parler d'auteurs scholastiques?” In Auctor et auctoritas: Invention et conformisme dans l'écriture médievale, ed. Michel Zimmermann (Paris: École des Chartes, 2001).

Barzizza, Gasparino, Gasparini Barzizii Bergomatis et Guiniforti Filii Opera, ed. J. Furiettus, Vol. 1 (Rome, 1723).

Campori, Giuseppe, Notizie dei miniatori dei Principi Estensi (Modena: Carlo Vincenzi, 1872).

Cappelli, Adriano, "La Biblioteca estense nella prima metà del secolo XV" in Giornale storico della letteratura italiana 14 (1889), 1-80

Carruthers, Mary, The Book of Memory (Cambridge: Cambridge University Press, 1992).

Castiglione, Baldesar, Libro del Cortegiano, ed. Giulio Carnazzi (Milan: Biblioteca Universale Rizzoli, 1987).

Celenza, Christopher S., "Creating Canons in Fifteenth-Century Ferrara: Angelo Decembrio's De Politia Litteraria 1.10”, Renaissance Quarterly, 57 (2004), 43-98.

— The Lost Italian Renaissance (Baltimore: Johns Hopkins University Press, 2004).

Churchill, William Algernon, Watermarks in Paper in Holland, England, France, etc., in the XVII and XVTII Centuries and their Interconnection (Nieuwkoop: B. De Graaf, 1935, repr. 1985).

Dean, Trevor, Land and Power in Late Medieval Ferrara (Cambridge: Cambridge University Press, 2002).

von Euw, Anton and Joahim von Plotzek, Die Handschriften der Sammlung Ludwig (4 vols.) (Cologne: Schnütgen-Museum der Stadt Köln, 1979-1985).

Forgeng, Jeffrey, Pietro Monte's Collectanea: The Arms, Armour and Fighting Techniques of a Fifteenth-Century Soldier (Martlesham: Boydell and Brewer, 2018).

Franceschini, Adriano, Artisti a Ferrara in età umanistica e rinascimentale: testimonianze archivistiche pt. 1. Dal 1341 al 1471 (Ferrara: Gabriele Corbo, 1993).

Gardner, Edmund G., Dukes and Poets in Ferrara (New York: Haskell House, 1968).

Gundersheimer, Werner L., Ferarra: The Style of a Renaissance Depotism (Princeton: Princeton University Press, 1973).

Howe, Russ, "Fiore dei Liberi: Origins and Motivations." The Journal of Western Martial Arts (2008), online

<http://ejmas.com/jwma/articles/2008/jwmaart_howe_0808.htm> (accessed October 26, 2012). 
Leoni, Tom, Fior di Battaglia Second English Edition (Wheaton: Freelance Academy Press, 2012).

Malipiero, Massimo, Il Fior di battaglia di Fiore dei Liberi da Cividale: Il Codice Ludwig XV 13 del J. Paul Getty Museum (Udine: Ribis, 2006).

Mondschein, Ken, "Introduction” in Fencing: A Renaissance Treatise (New York: Italica Press, revised edition, 2014).

, The Knightly Art of Battle (Los Angeles: Getty Publications, 2011).

, "The Medieval Experience of Time: Aristotle, Universals, and Technologies"

in Can These Bones Come to Life: Historical European Martial Arts Vol. 1. (Wheaton IL:

Freelance Academy Press, 2014), 30-37.

, "The Italian Schools of Fencing: Art, Science, and Pedagogy" in Late Medieval and Early Modern Fight Books: Transmission and Tradition of Martial Arts in Europe (14 17th Centuries) ed. Daniel Jaquet, Karin Verelst and Timothy Dawson (Leiden: Brill, 2016).

Nickel, Helmut, "A Heraldic Note about the Portrait of Ladislaus, Count of Haag, by Hans Mielich," Metropolitan Museum Journal 22 (1987), 145-47.

Novati, Francesco, Flos duellatorum: Il Fior di battaglia di maestro Fiore dei Liberi da Premariacco (Bergamo: Giardini Editori, 1902).

Rapisardi, Giovanni, Flos Duellatorum in armis, sine armis, equester et pedester (Padua: Gladiatoria, 1998).

Rubboli, Marco and Luca Cesari, Flos Duellatorum: Manuale di Arte del Combattimento del XV secolo (Rome: Il Cerchio, 2002).

Tlusty, B. Ann, The Martial Ethic in Early Modern Germany (New York: Palgrave, 2011).

Vadi, Filippo, Arte Gladiatoria Dimicandi: 15th Century Swordsmanship of Master Filippo Vadi, translated by Luca Porzio and Greg Mele (Union City: Chivalry Bookshelf, 2002).

Zanutto, Luigi, Fiore dei Liberi da Premariacco e i ludi e le festi marziali in Friuli nel Medio-evo (Udine: del Bianco, 1907). 


\section{APPENDIX: CONCORDANCE}

The following is a concordance of the Paris MS to the other three known Fiore manuscripts. This schema denotes the positions of illustrations on the page of the Paris, Morgan, Getty and some pages of the Pisani-Dossi MSS:

\begin{tabular}{|l|l|}
\hline $\mathrm{a}$ & $\mathrm{b}$ \\
\hline $\mathrm{c}$ & $\mathrm{d}$ \\
\hline
\end{tabular}

Thus, "ab" indicates the entire top register and "cd" the entire bottom. Those folios of the Pisani-Dossi which have six registers are represented thusly:

\begin{tabular}{|c|c|}
\hline$a$ & $b$ \\
\hline$c$ & $d$ \\
\hline$e$ & $f$ \\
\hline
\end{tabular}

\begin{tabular}{|c|c|c|c|l|}
\hline Paris & Getty & Morgan & $\begin{array}{c}\text { Pisani- } \\
\text { Dossi60 }\end{array}$ & \multicolumn{1}{|c|}{ Description and Notes $^{61}$} \\
\hline $1 \mathrm{v}$ & $32 \mathrm{r}$ & N/A & $17 \mathrm{r}$ & $\begin{array}{l}\text { Segno. Note that the PD also illustrates the } \\
\text { angles of attack on 12v-e-13r-b. }\end{array}$ \\
\hline $2 \mathrm{r}-\mathrm{ab}$ & $41 \mathrm{r}-\mathrm{ab}$ & $3 \mathrm{r}-\mathrm{ab}$ & $29 \mathrm{r}-\mathrm{ab}$ & $\begin{array}{l}\text { First master of mounted lance (dente di } \\
\text { cinghiaro) }\end{array}$ \\
\hline $2 \mathrm{r}-\mathrm{cd}$ & $41 \mathrm{v}-\mathrm{ab}$ & $3 \mathrm{v}-\mathrm{ab}$ & $29 \mathrm{v}-\mathrm{ab}$ & $\begin{array}{l}\text { Third master of mounted lance, showing counter } \\
\text { to first master of mounted lance (left posta di } \\
\text { donna) }\end{array}$ \\
\hline $2 \mathrm{v}-\mathrm{ab}$ & $42 \mathrm{r}-\mathrm{cd}$ & $3 \mathrm{v}-\mathrm{cd}$ & $30 \mathrm{r}-\mathrm{cd}$ & $\begin{array}{l}\text { First master of mounted sword, showing counter } \\
\text { to first master of mounted lance (left posta di } \\
\text { donna) }\end{array}$ \\
\hline $2 \mathrm{v}-\mathrm{cd}$ & N/A & N/A & $31 \mathrm{r}-\mathrm{ab}$ & $\begin{array}{l}\text { Counter to first master of mounted sword vs. } \\
\text { lance (holding lance to the left with both hands). }\end{array}$ \\
\hline
\end{tabular}

\footnotetext{
59 Using the Getty's foliation, not Malpiero's, numbering from the first surviving folio and not using the penciled-in numbers on the upper right

${ }^{60}$ Using Novati's numbering

${ }^{61}$ Based on the Getty's catalogue of techniques

62 Note the Morgan also has the master with the cord attached to his saddle on $2 \mathrm{v}$-ab (the reverse of the second page of the preface), perhaps as an afterthought.
} 


\begin{tabular}{|c|c|c|c|c|}
\hline Paris & Getty ${ }^{59}$ & Morgan & $\begin{array}{l}\text { Pisani- } \\
\text { Dossi60 }\end{array}$ & Description and Notes ${ }^{61}$ \\
\hline $3 r-a b$ & $42 r-a b$ & $4 r-a b$ & $30 r-a b$ & Defense against a pursuing opponent \\
\hline $3 r-c d$ & $43 v-a$ & $5 v-a b$ & $31 v-a b$ & $\begin{array}{l}\text { Third master of mounted fencing (coda lunga). } \\
\text { Note that the Morgan has the sword drawn in } \\
\text { front of the adversary's face (posta di finestra). }\end{array}$ \\
\hline $3 v-a b$ & $44 \mathrm{r}-\mathrm{a}$ & $6 r-a$ & $32 r-a$ & $\begin{array}{l}\text { First scholar of third master of mounted fencing } \\
\text { (thrust to face) }\end{array}$ \\
\hline $3 v-c d$ & $44 r-b$ & $6 r-c$ & $32 \mathrm{r}-\mathrm{c}$ & $\begin{array}{l}\text { Second scholar of third master of mounted } \\
\text { fencing (cut to head) }{ }^{63}\end{array}$ \\
\hline $4 \mathrm{r}-\mathrm{ab}$ & $44 r-d$ & $6 v-a^{64}$ & $32 \mathrm{v}-\mathrm{a}$ & $\begin{array}{l}\text { Fourth scholar of third master of mounted } \\
\text { fencing (disarm) }\end{array}$ \\
\hline $4 r-c d$ & $44 v-b$ & $6 v-c$ & $32 \mathrm{v}-\mathrm{C}$ & $\begin{array}{l}\text { Fifth scholar of third master of mounted fencing } \\
\text { (arm wrap around neck) }\end{array}$ \\
\hline $4 v-a b$ & $44 v-d$ & $7 r-a$ & $33 r-a$ & $\begin{array}{l}\text { Eighth scholar of third master of mounted } \\
\text { fencing (pommel strike to face) }\end{array}$ \\
\hline $4 \mathrm{v}-\mathrm{cd}$ & $45 v-b$ & $8 \mathrm{r}-\mathrm{a}$ & $33 v-c$ & $\begin{array}{l}\text { Student of mounted wrestling showing how to } \\
\text { bear a horse and man to the ground }\end{array}$ \\
\hline $5 r-a b$ & $45 r-b$ & $7 \mathrm{v}-\mathrm{a}$ & $33 r-c$ & $\begin{array}{l}\text { First master of mounted wrestling showing catch } \\
\text { from behind } 65\end{array}$ \\
\hline $5 r-c d$ & $45 r-c$ & $7 v-b$ & $33 r-d$ & Counter to first master of mounted wrestling \\
\hline $5 v-a b$ & $45 r-d$ & $7 \mathrm{v}-\mathrm{c}$ & $\mathrm{N} / \mathrm{A}$ & $\begin{array}{l}\text { Second master of mounted wrestling showing } \\
\text { stirrup pick-up }\end{array}$ \\
\hline $5 v-c d$ & $45 v-a$ & $7 v-d$ & N/A & Counter to second master of mounted wrestling \\
\hline $6 r-a b$ & $46 r-a b$ & $8 \mathrm{r}-\mathrm{cd}$ & $34 r-a b$ & Master of footman vs. horseman \\
\hline $6 r-c d$ & $46 r-c$ & $8 v-a$ & $34 \mathrm{r}-\mathrm{c}$ & First scholar of master of footman vs. horseman \\
\hline $6 v-a b$ & $46 r-d$ & $8 \mathrm{~V}-\mathrm{c}$ & $34 r-d$ & $\begin{array}{l}\text { Second scholar of master of footman vs. } \\
\text { horseman }\end{array}$ \\
\hline $6 \mathrm{v}-\mathrm{cd}$ & $39 r-a b$ & $9 r-a$ & $15 v-a$ & First master of the spear (tutta porta di ferro) \\
\hline $7 r-a b$ & $39 r-b c$ & $9 r-b$ & $15 v-b$ & $\begin{array}{l}\text { Second master of the spear (mezza porta di } \\
\text { ferro) }\end{array}$ \\
\hline
\end{tabular}

${ }^{63}$ Note that the Morgan has another image on 6r-b showing the swords crossed.

${ }^{64}$ Note the Morgan shows the hilt of the scholar's sword over the adversary's right wrist.

65 Note the Morgan shows this technique being done at the walk 


\begin{tabular}{|c|c|c|c|c|}
\hline Paris & Getty ${ }^{59}$ & Morgan & $\begin{array}{l}\text { Pisani- } \\
\text { Dossi60 }\end{array}$ & Description and Notes ${ }^{61}$ \\
\hline $7 \mathrm{r}-\mathrm{cd}$ & $40 r-a b$ & $9 r-c$ & $15 v-c$ & $\begin{array}{l}\text { Third master of the spear (posta di finestra). The } \\
\text { shaft of the spear in the Paris should be in front } \\
\text { of the face. }\end{array}$ \\
\hline $7 v-a b$ & $39 v-c$ & $9 r-d$ & $15 v-d$ & $\begin{array}{l}\text { First scholar of the three masters of the spear. } \\
\text { The Paris adds a crown. }\end{array}$ \\
\hline $7 \mathrm{v}-\mathrm{cd}$ & $39 v-d$ & $9 v-d$ & $\mathrm{~N} / \mathrm{A}$ & $\begin{array}{l}\text { Counter to the first scholar of the three masters } \\
\text { of the spear. } 66\end{array}$ \\
\hline $8 r-a b$ & $31 \mathrm{r}-\mathrm{bc}$ & $18 \mathrm{r}-\mathrm{c}$ & $16 r-a$ & $\begin{array}{l}\text { Technique with staff (in the Paris, a spear) and } \\
\text { dagger }\end{array}$ \\
\hline $8 \mathrm{r}-\mathrm{cd}$ & $31 v-b$ & $\mathrm{~N} / \mathrm{A}$ & $15 r-c$ & Technique with two clubs and dagger \\
\hline $8 v-a b$ & $31 v-c$ & $\mathrm{~N} / \mathrm{A}$ & $15 r-d$ & $\begin{array}{l}\text { Conclusion of technique with two clubs and } \\
\text { dagger }\end{array}$ \\
\hline $8 v-c$ & $35 \mathrm{v}-\mathrm{a}$ & $\mathrm{N} / \mathrm{A}$ & $27 r-a$ & $\begin{array}{l}\text { First master of the axe (posta breve la } \\
\text { serpentina) }\end{array}$ \\
\hline $8 v-d$ & $35 v-b$ & $\mathrm{~N} / \mathrm{A}$ & $27 r-b$ & Second master of the axe (vera croce) \\
\hline $9 r-a$ & $35 \mathrm{v}-\mathrm{c}$ & $\mathrm{N} / \mathrm{A}$ & $27 r-c$ & Third master of the axe (posta di donna) \\
\hline $9 r-b$ & $35 v-d$ & $\mathrm{~N} / \mathrm{A}$ & $27 r-d$ & $\begin{array}{l}\text { Fourth master of the axe (porta di ferro } \\
\text { mezzana) }\end{array}$ \\
\hline 9r-cd & $36 v-a$ & $\mathrm{~N} / \mathrm{A}$ & $27 v-a$ & First scholar of the axe \\
\hline $9 v-a b$ & $36 v-c$ & $\mathrm{~N} / \mathrm{A}$ & $27 v-b$ & $\begin{array}{l}\text { Third scholar of the axe. Note the positions of } \\
\text { the figures are reversed in the Getty, and the } \\
\text { scholar is also stepping on the opponent's axe, } \\
\text { whereas he is not in the Paris and PD. }\end{array}$ \\
\hline $9 \mathrm{v}-\mathrm{cd}$ & $36 v-d$ & $\mathrm{~N} / \mathrm{A}$ & $27 v-c$ & Fourth scholar of the axe \\
\hline $10 r-a b$ & $37 r-b$ & $\mathrm{~N} / \mathrm{A}$ & $28 r-a$ & Sixth scholar of the axe \\
\hline $10 \mathrm{r}-\mathrm{cd}$ & $20 r-c d$ & $17 v-a b$ & $13 r-c$ & $\begin{array}{l}\text { Master of the sword in one hand (with three } \\
\text { attackers) }\end{array}$ \\
\hline $10 v-a b$ & $20 v-a$ & $20 \mathrm{v}-\mathrm{c}$ & $13 r-d$ & $\begin{array}{l}\text { First scholar of the master of the sword in one } \\
\text { hand. Note that the Getty and Morgan } \\
\text { illustrations show the scholar with his hands } \\
\text { about to cross over the adversary's; the Pisani- } \\
\text { Dossi, like the Paris, does not. }\end{array}$ \\
\hline
\end{tabular}

${ }^{66}$ Note the strike in the Paris should be with the butt of the spear, as described in the Getty; in this it is more similar to the Morgan, which is not shown as a counter-master. 


\begin{tabular}{|c|c|c|c|c|}
\hline Paris & Getty ${ }^{59}$ & Morgan & $\begin{array}{l}\text { Pisani- } \\
\text { Dossi60 }\end{array}$ & Description and Notes ${ }^{61}$ \\
\hline $10 \mathrm{v}-\mathrm{cd}$ & $21 \mathrm{v}-\mathrm{c}$ & 19r-a & $13 \mathrm{v}-\mathrm{a}$ & $\begin{array}{l}\text { Eleventh scholar of the sword in one hand, half- } \\
\text { sword to the chest }\end{array}$ \\
\hline $11 \mathrm{r}-\mathrm{ab}$ & $20 v-b$ & $17 v-d$ & $13 v-b$ & $\begin{array}{l}\text { Second scholar of the sword in one hand, cut to } \\
\text { the head. The Morgan shows the positions } \\
\text { reversed. }\end{array}$ \\
\hline $11 \mathrm{r}-\mathrm{cd}$ & $20 \mathrm{v}-\mathrm{C}$ & $\mathrm{N} / \mathrm{A}$ & $\mathrm{N} / \mathrm{A}$ & $\begin{array}{l}\text { Third scholar of the sword in one hand, seizing } \\
\text { the opponent's handle with one's left hand with } \\
\text { his right foot forward }\end{array}$ \\
\hline $11 v-a b$ & $20 \mathrm{v}-\mathrm{a}$ & $\bar{N} / \mathrm{A}$ & $13 v-d$ & $\begin{array}{l}\text { First scholar of the master of the sword in one } \\
\text { hand, reaching over from the inside with the left } \\
\text { hand }\end{array}$ \\
\hline $11 \mathrm{v}-\mathrm{cd}$ & $21 r-a$ & $\mathrm{~N} / \mathrm{A}$ & $14 r-b$ & $\begin{array}{l}\text { Fifth scholar of the sword in one hand, seizing } \\
\text { the hilt with the left hand with his left foot forward }\end{array}$ \\
\hline $12 \mathrm{r}-\mathrm{ab}$ & $(21 r-c)$ & $\bar{N} / \mathrm{A}$ & $(14 v-a)$ & $\begin{array}{l}\text { Seventh scholar of the sword in one hand, } \\
\text { slicing the neck from behind. Note that the Paris } \\
\text { illustration is quite different from the Getty and } \\
\text { Pisani-Dossi, showing a counter to the } \\
\text { technique shown in those MSS. }\end{array}$ \\
\hline $12 r-b c$ & $21 \mathrm{v}-\mathrm{a}$ & $\mathrm{N} / \mathrm{A}$ & $14 r-d$ & $\begin{array}{l}\text { Ninth scholar of the sword in one hand, elbow } \\
\text { turn. The Paris illustration is again different from } \\
\text { the Pisani-Dossi and Getty, showing the } \\
\text { beginning of the technique, whereas the other } \\
\text { MSS show the midpoint and end, respectively. }\end{array}$ \\
\hline $12 v-a$ & $23 v-a$ & $12 \mathrm{r}-\mathrm{a}$ & $18 \mathrm{r}-\mathrm{a}$ & Sword in two hands: porta di ferro \\
\hline $12 v-b$ & $23 v-b$ & $\begin{array}{l}12 r-b \\
12 v-c\end{array}$ & $18 r-b$ & Sword in two hands: posta di donna (right) ${ }^{67}$ \\
\hline $12 \mathrm{v}-\mathrm{c}$ & $23 v-c$ & $12 r-c$ & $18 \mathrm{r}-\mathrm{c}$ & Sword in two hands: posta di finestra (right) \\
\hline $12 v-d$ & $24 r-b$ & $\overline{12 r-d}$ & $18 r-d$ & Sword in two hands: porta di ferro mezzana \\
\hline $13 r-a$ & $24 r-a$ & $12 \mathrm{v}-\mathrm{a}$ & $18 v-a$ & Sword in two hands: Posta Longa \\
\hline $13 r-b$ & $24 v-c$ & $12 v-b$ & $18 v-b$ & Sword in two hands: frontale/corona \\
\hline $13 r-c$ & $23 v-d$ & $13 r-b$ & $18 \mathrm{v}-\mathrm{C}$ & Sword in two hands: posta di donna (left) \\
\hline $13 r-d$ & $\begin{array}{l}24 r-d / 24 v- \\
d^{68}\end{array}$ & $12 \mathrm{v}-\mathrm{d}$ & $18 v-d$ & Sword in two hands: dente di cinghiaro \\
\hline
\end{tabular}

67 The Morgan shows a second posta di donna from a different view; the second may have been intended as a posta di finestra, though the text describes the posta di donna. 


\begin{tabular}{|c|c|c|c|c|}
\hline Paris & Getty ${ }^{59}$ & Morgan & $\begin{array}{l}\text { Pisani- } \\
\text { Dossi60 }\end{array}$ & Description and Notes ${ }^{61}$ \\
\hline $13 v-a$ & $24 r-c$ & $13 r-a$ & $19 r-a$ & Sword in two hands: posta breve \\
\hline $13 v-b$ & $\mathrm{~N} / \mathrm{A}$ & $\mathrm{N} / \mathrm{A}$ & $19 r-b$ & Sword in two hands: posta di finestra (left) \\
\hline $13 v-c$ & $24 v-a$ & $13 r-c$ & $19 r-c$ & Sword in two hands: posta di coda lunga \\
\hline $13 v-d$ & $24 v-b$ & $13 r-d$ & $19 r-d$ & Sword in two hands: posta di bicorno \\
\hline $14 r-a b$ & $25 r-c$ & $13 v-a$ & $19 v-a$ & $\begin{array}{l}\text { First master of the two-handed sword, wide play: } \\
\text { swords engaged at the foibles }\end{array}$ \\
\hline $14 r-c d$ & $25 r-d$ & $13 v-b$ & $19 v-b$ & $\begin{array}{l}\text { First student of the first master of the two- } \\
\text { handed sword, wide play: Hit to the head }\end{array}$ \\
\hline $14 v-a b$ & $25 \mathrm{v}-\mathrm{a}$ & $13 v-c$ & $19 v-c$ & $\begin{array}{l}\text { First master of the two-handed sword, medium } \\
\text { play. Note that the Paris shows the swords } \\
\text { engaged relatively close. }\end{array}$ \\
\hline $14 \mathrm{v}-\mathrm{cd}$ & $25 v-d$ & $13 v-d$ & $19 v-d$ & $\begin{array}{l}\text { First student of the first master of the two- } \\
\text { handed sword, medium play: Hit to the arm. }\end{array}$ \\
\hline $15 r-a b$ & $26 v-a$ & $14 \mathrm{v}-\mathrm{c}$ & $20 \mathrm{v}-\mathrm{c}$ & $\begin{array}{l}\text { Exchange of thrusts. Note the Morgan has the } \\
\text { sword positioned lower. }\end{array}$ \\
\hline $15 r-b c$ & $26 v-b$ & $14 \mathrm{v}-\mathrm{d}$ & $20 \mathrm{v}-\mathrm{d}$ & Play following up from exchange of thrusts \\
\hline $15 v-a b$ & $26 v-c$ & $\mathrm{~N} / \mathrm{A}$ & $21 r-b$ & Breaking the thrust \\
\hline $15 \mathrm{v}-\mathrm{cd}$ & $26 v-d$ & $\mathrm{~N} / \mathrm{A}$ & $21 r-c$ & $\begin{array}{l}\text { Second part of breaking the thrust: Stepping on } \\
\text { the sword. Note the PD shows the scholar on } \\
\text { the left. }\end{array}$ \\
\hline $16 r-a b$ & $34 v-b$ & $11 \mathrm{r}-\mathrm{a}$ & $26 r-b$ & $\begin{array}{l}\text { Sixth scholar of master of vera croce for half- } \\
\text { sword in armor: sword around the neck }\end{array}$ \\
\hline $16 r-c d$ & $34 v-c$ & $11 r-c$ & $26 r-c$ & $\begin{array}{l}\text { Seventh scholar of master of vera croce for half- } \\
\text { sword in armor: Leverage the wrist }\end{array}$ \\
\hline $16 v-a b$ & $34 v-a$ & $11 \mathrm{r}-\mathrm{d}$ & $26 r-d$ & $\begin{array}{l}\text { Fifth scholar of master of vera croce for half- } \\
\text { sword in armor: Thrust to the face }\end{array}$ \\
\hline $16 \mathrm{v}-\mathrm{cd}$ & $\mathrm{N} / \mathrm{A}$ & $11 \mathrm{v}-\mathrm{a}$ & $26 v-a$ & $\begin{array}{l}\text { Seventh play of half-sword in armor from PD } \\
\text { and Morgan: Cut/crush the hand }\end{array}$ \\
\hline $17 r-a b$ & $\mathrm{~N} / \mathrm{A}$ & $11 v-b$ & $26 v-b$ & $\begin{array}{l}\text { Play of half-sword in armor from the PD: } \\
\text { Pommel throw w./ trapped sword }\end{array}$ \\
\hline
\end{tabular}

68 The Paris shows a left and right posta di finestra, whereas the Getty shows two variations on the dente di chingiaro. 


\begin{tabular}{|c|c|c|c|c|}
\hline Paris & Getty ${ }^{59}$ & Morgan & $\begin{array}{l}\text { Pisani- } \\
\text { Dossi60 }\end{array}$ & Description and Notes ${ }^{61}$ \\
\hline $17 r-c d$ & $34 r-d$ & $11 v-c$ & $26 v-c$ & $\begin{array}{l}\text { Fourth scholar of master of vera croce for half- } \\
\text { sword in armor: Throw with pommel from } \\
\text { underneath adversary's arm. }\end{array}$ \\
\hline $17 v-a b$ & $34 v-d$ & $11 v-d$ & $26 v-d$ & $\begin{array}{l}\text { Eighth scholar for half-sword in armor: Pin right } \\
\text { hand, thrust to face. }\end{array}$ \\
\hline $17 \mathrm{v}-\mathrm{cd}$ & $33 v-c$ & $\mathrm{~N} / \mathrm{A}$ & $\mathrm{N} / \mathrm{A}$ & Low bind for half-sword in armor \\
\hline $18 r-a$ & $32 \mathrm{v}-\mathrm{c}$ & $10 \mathrm{r}-\mathrm{c}$ & $25 r-c$ & (Posta) serpentino lo soprano \\
\hline $18 r-b$ & $\mathrm{~N} / \mathrm{A}$ & $\mathrm{N} / \mathrm{A}$ & $\mathrm{N} / \mathrm{A}$ & Leopard posta ${ }^{69}$ \\
\hline $18 \mathrm{r}-\mathrm{cd}$ & $33 r-c$ & $10 v-c$ & $25 v-c$ & $\begin{array}{l}\text { Parry from vera croce for half-sword in armor. } \\
\text { Note the Morgan has the sword positioned } \\
\text { slightly differently }\end{array}$ \\
\hline $18 v-a b$ & $33 r-d$ & $10 v-d$ & $25 v-d$ & $\begin{array}{l}\text { First scholar of master of vera croce for half- } \\
\text { sword in armor: Thrust to the face }\end{array}$ \\
\hline $18 \mathrm{v}-\mathrm{cd}$ & $34 r-a$ & $11 \mathrm{r}-\mathrm{a}$ & $26 r-a$ & $\begin{array}{l}\text { Play from the master of vera croce for half- } \\
\text { sword in armor: Throw from behind }\end{array}$ \\
\hline $19 r$ & $\mathrm{~N} / \mathrm{A}$ & $\mathrm{N} / \mathrm{A}$ & $\mathrm{N} / \mathrm{A}$ & (blank) \\
\hline $19 v-a$ & $32 \mathrm{v}-\mathrm{a}$ & $10 \mathrm{r}-\mathrm{a}$ & $25 r-a$ & $\begin{array}{l}\text { Master of posta breve la serpentina for half- } \\
\text { sword in armor }\end{array}$ \\
\hline $19 v-b$ & $32 v-b$ & $10 r-b$ & $25 r-b$ & Master of vera croce for half-sword in armor \\
\hline $19 \mathrm{v}-\mathrm{c}$ & $33 r-a$ & $10 v-a$ & $25 v-a$ & Master of posta sagittaria for half-sword in armor \\
\hline $19 v-d$ & $32 \mathrm{v}-\mathrm{a}$ & 10r-d & $25 r-d$ & $\begin{array}{l}\text { Master of porta di ferro mezzana for half-sword } \\
\text { in armor }\end{array}$ \\
\hline $20 r-a b$ & $19 r-b$ & $18 v-a$ & $\mathrm{~N} / \mathrm{A}$ & Dagger defense vs. sword thrust \\
\hline $20 \mathrm{r}-\mathrm{cd}$ & $19 r-c$ & $18 v-b$ & $\mathrm{~N} / \mathrm{A}$ & Counter to previous play \\
\hline $20 v-a b$ & $19 r-d$ & $18 \mathrm{v}-\mathrm{c}$ & $\mathrm{N} / \mathrm{A}$ & Dagger vs. sword cut \\
\hline $20 \mathrm{v}-\mathrm{cd}$ & $19 v-c$ & $\mathrm{~N} / \mathrm{A}$ & $\mathrm{N} / \mathrm{A}$ & Sword draw and defense against dagger attack \\
\hline $21 r-a$ & $10 \mathrm{r}-\mathrm{a}$ & $\mathrm{N} / \mathrm{A}$ & $6 r-a$ & First dagger remedy master \\
\hline $21 r-b$ & $10 \mathrm{r}-\mathrm{b}$ & $\mathrm{N} / \mathrm{A}$ & $6 r-b$ & Second dagger remedy master \\
\hline $21 r-c$ & 10r-c & $\mathrm{N} / \mathrm{A}$ & $6 r-c$ & er remedy master \\
\hline
\end{tabular}

${ }^{69}$ This guard, for use in armor, looks similar to posta di donna, but is not found in any of the other MSS. It seems to perform the same functions as the master of vera croce. We do find it, however, in Vadi (folio 26r) and the Austrian National Library Codex 5278 (folio 180r). The Paris omits bastarda vera croce (Getty 33r-b, Morgan 10v-b, Pisani-Dossi 25v-b). 


\begin{tabular}{|c|c|c|c|c|}
\hline Paris & Getty ${ }^{59}$ & Morgan & $\begin{array}{l}\text { Pisani- } \\
\text { Dossi60 }\end{array}$ & Description and Notes ${ }^{61}$ \\
\hline $21 \mathrm{r}-\mathrm{d}$ & $10 \mathrm{r}-\mathrm{d}$ & $\mathrm{N} / \mathrm{A}$ & $6 r-d$ & Fourth dagger remedy master ${ }^{70}$ \\
\hline $21 v-a b$ & $10 v-a$ & $\mathrm{~N} / \mathrm{A}$ & $6 r-e$ & First dagger master \\
\hline $21 \mathrm{v}-\mathrm{cd}$ & $10 v-b$ & $\mathrm{~N} / \mathrm{A}$ & $6 r-f$ & Counter-master to first dagger master \\
\hline $22 r-a b$ & $13 r-c$ & $\mathrm{~N} / \mathrm{A}$ & $\mathrm{N} / \mathrm{A}$ & $\begin{array}{l}\text { Counter-master to the master of the cross-block } \\
\text { (porta di ferro mezzana) }\end{array}$ \\
\hline $22 r-c d$ & $13 v-b$ & $\mathrm{~N} / \mathrm{A}$ & $8 \mathrm{v}-\mathrm{c}$ & $\begin{array}{l}\text { First action against a reverse (left to right) } \\
\text { dagger strike }\end{array}$ \\
\hline $22 v-a b$ & $13 \mathrm{v}-\mathrm{c}$ & $\mathrm{N} / \mathrm{A}$ & $8 v-d$ & $\begin{array}{l}\text { Second action against a reverse (left to right) } \\
\text { dagger strike }\end{array}$ \\
\hline $22 \mathrm{v}-\mathrm{cd}$ & $13 v-d$ & $\mathrm{~N} / \mathrm{A}$ & $8 v-e$ & $\begin{array}{l}\text { Third action against a reverse (left to right) } \\
\text { dagger strike }\end{array}$ \\
\hline $23 r-a b$ & $12 r-d$ & $\mathrm{~N} / \mathrm{A}$ & $7 r-c$ & $\begin{array}{l}\text { Dagger defense against a forehand attack with } \\
\text { arm break over the shoulder }\end{array}$ \\
\hline $23 r-c d$ & $12 v-b$ & $\mathrm{~N} / \mathrm{A}$ & $7 \mathrm{r}-\mathrm{e}$ & $\begin{array}{l}\text { Dagger defense against a forehand attack with } \\
\text { disarm }\end{array}$ \\
\hline $23 v-a b$ & $\begin{array}{c}12 v- \\
d / 14 v-d\end{array}$ & $\mathrm{~N} / \mathrm{A}$ & $7 v-a$ & $\begin{array}{l}\text { Dagger defense against a forehand attack with } \\
\text { leg pick-up }\end{array}$ \\
\hline $23 v-c d$ & $13 r-b$ & $\mathrm{~N} / \mathrm{A}$ & $7 r-c$ & $\begin{array}{l}\text { Master of dagger defense with crossed arms. } \\
\text { Note that the Paris figure is lacking its crown. }\end{array}$ \\
\hline $24 r-a b$ & $10 \mathrm{v}-\mathrm{c}$ & $\mathrm{N} / \mathrm{A}$ & $6 v-a$ & $\begin{array}{l}\text { Dagger defense called "middle bind" in the } \\
\text { Getty. This begins a section of dagger defenses } \\
\text { and counters. }\end{array}$ \\
\hline $24 r-c d$ & $10 v-d$ & $\mathrm{~N} / \mathrm{A}$ & $6 v-b$ & $\begin{array}{l}\text { Counter to previous dagger defense with middle } \\
\text { bind }\end{array}$ \\
\hline $24 v-a b$ & $11 \mathrm{r}-\mathrm{a}$ & $\mathrm{N} / \mathrm{A}$ & $6 v-c$ & Another dagger defense going into middle bind \\
\hline $23 v-c d$ & $11 r-b$ & $\mathrm{~N} / \mathrm{A}$ & $6 v-d$ & $\begin{array}{l}\text { Counter to previous dagger defense with middle } \\
\text { bind }\end{array}$ \\
\hline $25 r-a b$ & $11 v-d$ & $\mathrm{~N} / \mathrm{A}$ & $6 v-e$ & $\begin{array}{l}\text { Student of first remedy master with figure-four } \\
\text { armlock }\end{array}$ \\
\hline $25 r-c d$ & $12 r-a$ & $\mathrm{~N} / \mathrm{A}$ & $6 v-f$ & Counter to previous dagger defense \\
\hline $25 v-a b$ & $12 r-b$ & $\mathrm{~N} / \mathrm{A}$ & $7 \mathrm{r}-\mathrm{a}$ & $\begin{array}{l}\text { Dagger defense called "more strength" (piu } \\
\text { forteza) in the Getty and PD }\end{array}$ \\
\hline
\end{tabular}

${ }^{70}$ Note the differences in text between this version and the Pisani-Dossi Latin 


\begin{tabular}{|c|c|c|c|c|}
\hline Paris & Getty ${ }^{59}$ & Morgan & $\begin{array}{l}\text { Pisani- } \\
\text { Dossi60 }\end{array}$ & Description and Notes ${ }^{61}$ \\
\hline $25 v-c d$ & $12 r-c$ & $\mathrm{~N} / \mathrm{A}$ & $7 r-b$ & Counter to "more strength" dagger defense \\
\hline $26 r-a b$ & $27 \mathrm{r}-\mathrm{a}$ & $\mathrm{N} / \mathrm{A}$ & $21 \mathrm{r}-\mathrm{a}$ & $\begin{array}{l}\text { Counter to a sword thrust (per the Getty and } \\
\text { Morgan) with stepping on the sword. This begins } \\
\text { a section on two-handed sword at medium } \\
\text { range. }^{71}\end{array}$ \\
\hline $26 r-c d$ & $28 r-b$ & $16 r-b$ & $20 v-d$ & $\begin{array}{l}\text { Play from the cross in the middle of the swords, } \\
\text { grasping the adversary's handle. }\end{array}$ \\
\hline $26 v-a b$ & $28 \mathrm{r}-\mathrm{c}$ & $16 r-c$ & $22 r-c$ & One-handed pommel strike \\
\hline $26 v-c d$ & $28 r-d$ & 16r-d & $22 r-d$ & Two-handed pommel strike \\
\hline $27 r-a b$ & $28 \mathrm{v}-\mathrm{c}$ & $16 v-c$ & $23 r-b$ & Sword bind with overarm wrap \\
\hline $27 r-c d$ & $28 v-a$ & $16 v-a$ & $22 \mathrm{v}-\mathrm{c}$ & $\begin{array}{l}\text { Sword wrap around the neck. Note that the } \\
\text { Getty specifies this the follow-up to the } \\
\text { technique shown in Paris } 26 \mathrm{v} \text {-cd }\end{array}$ \\
\hline $27 v-a b$ & $28 v-b$ & $16 v-b$ & $22 \mathrm{v}-\mathrm{d}$ & Arm-bind \\
\hline $27 v-c d$ & $\mathrm{~N} / \mathrm{A}$ & $\mathrm{N} / \mathrm{A}$ & $\mathrm{N} / \mathrm{A}$ & $\begin{array}{l}\text { Arm trap. This play is not in any of the other } \\
\text { MSS. }\end{array}$ \\
\hline $28 r-a b$ & $(29 v-c)$ & $15 v-d$ & $\mathrm{~N} / \mathrm{A}$ & Counter to the play shown on Paris $26 r$-cd \\
\hline $28 r-c d$ & $29 \mathrm{v}-\mathrm{c}$ & $\mathrm{N} / \mathrm{A}$ & $23 v-d$ & $\begin{array}{l}\text { Completion of previous technique: Arm lock with } \\
\text { sword }\end{array}$ \\
\hline $28 v-a b$ & $28 v-d$ & $\mathrm{~N} / \mathrm{A}$ & $\mathrm{N} / \mathrm{A}$ & $\begin{array}{l}\text { Sword grapple with hilt between hands. It is also } \\
\text { unclear why this figure wears a crown in the } \\
\text { Paris. }\end{array}$ \\
\hline $28 \mathrm{v}-\mathrm{cd}$ & $(33 r-d)$ & $(10 v-d)$ & $(25 v-d)$ & $\begin{array}{l}\text { Similar to the first student of the first master's } \\
\text { play in armor; there is no indication this is the } \\
\text { falsa punta of Getty } 27 \mathrm{v}-\mathrm{a}\end{array}$ \\
\hline $29 r-a b$ & $30 r-c$ & $15 r-a$ & $24 r-b$ & $\begin{array}{l}\text { High disarm. Notice different foot positions } \\
\text { between the MSS. }\end{array}$ \\
\hline $29 r-c d$ & $30 v-a$ & $15 v-b$ & $24 r-c$ & $\begin{array}{l}\text { Middle disarm. Notice different foot positions } \\
\text { between the Getty/PD and Paris. }\end{array}$ \\
\hline $29 v-a b$ & $30 v-b$ & $15 v-c$ & $24 r-d$ & Low disarm \\
\hline $29 \mathrm{v}-\mathrm{cd}$ & $30 \mathrm{v}-\mathrm{c}$ & $15 v-d$ & $24 v-a$ & Another disarm, dropping the sword \\
\hline
\end{tabular}

71 Considering its anomalous place in the MS, this section may have been displaced during rebinding. 


\begin{tabular}{|c|c|c|c|c|}
\hline Paris & Getty ${ }^{59}$ & Morgan & $\begin{array}{l}\text { Pisani- } \\
\text { Dossi60 }\end{array}$ & Description and Notes ${ }^{61}$ \\
\hline $30 r-a b$ & $(30 r-b)$ & $15 r-c$ & $22 \mathrm{v}-\mathrm{c}$ & $\begin{array}{l}\text { Grapple with the sword placed around the neck. } \\
\text { Getty 30r-b may be a variation. }\end{array}$ \\
\hline 30r-cd & $30 r-b$ & $15 r-d$ & $22 \mathrm{v}-\mathrm{a}$ & Grapple with the sword placed around the neck \\
\hline $30 v-a b$ & $29 v-a$ & $15 v-a$ & $22 v-b$ & $\begin{array}{l}\text { Throw with the adversary's own sword around } \\
\text { his neck. Note that the discarded sword is not } \\
\text { shown in the Paris. }\end{array}$ \\
\hline $30 \mathrm{v}-\mathrm{cd}$ & $\mathrm{N} / \mathrm{A}$ & $\mathrm{N} / \mathrm{A}$ & $24 r-a$ & $\begin{array}{l}\text { Grapple with the right hand and strike with the } \\
\text { sword held in the left. Not in the Getty or } \\
\text { Morgan. This ends the section of sword plays at } \\
\text { medium range. }\end{array}$ \\
\hline $31 r-a b^{72}$ & $14 \mathrm{r}-\mathrm{a}$ & $\mathrm{N} / \mathrm{A}$ & $9 r-a$ & $\begin{array}{l}\text { Arm lock against a man with a dagger. This } \\
\text { continues the section of plays against a reverse } \\
\text { blow with a dagger. }\end{array}$ \\
\hline $31 \mathrm{r}-\mathrm{cd}$ & $14 r-b$ & $\mathrm{~N} / \mathrm{A}$ & $9 r-b$ & Low bind against dagger \\
\hline $31 v-a b$ & $14 r-c$ & $\mathrm{~N} / \mathrm{A}$ & $9 r-d$ & $\begin{array}{l}\text { Follow-up to previous, showing the low bind. } \\
\text { Note the dagger is not shown in the Getty. }\end{array}$ \\
\hline $31 v-c d$ & $14 r-d$ & $\mathrm{~N} / \mathrm{A}$ & $9 r-e$ & $\begin{array}{l}\text { Counter-master to the third master of dagger, } \\
\text { playing from the reverse side. Note that Getty } \\
\text { shows this from the other side. }\end{array}$ \\
\hline $32 r-a b$ & $14 v-a$ & $\mathrm{~N} / \mathrm{A}$ & $9 v-a$ & Fourth dagger master \\
\hline $32 r-c d$ & $14 v-b$ & $\mathrm{~N} / \mathrm{A}$ & $9 \mathrm{v}-\mathrm{c}$ & $\begin{array}{l}\text { Follow-up high bind to third master, grasping } \\
\text { adversary's arm in a figure-4. Note the different } \\
\text { position of the feet in the Paris/Getty and PD; } \\
\text { this is likely due to different phases of the same } \\
\text { throw being shown }\end{array}$ \\
\hline $32 v-a b$ & $14 \mathrm{v}-\mathrm{c}$ & $\mathrm{N} / \mathrm{A}$ & $9 v-d$ & $\begin{array}{l}\text { Another follow-up high bind to third master, } \\
\text { grasping owns arm in a figure-4 }\end{array}$ \\
\hline $32 \mathrm{v}-\mathrm{cd}$ & $14 v-d$ & $\mathrm{~N} / \mathrm{A}$ & $9 v-f$ & Follow-up leg pick-up to third master \\
\hline $33 r-a b$ & $38 r-a$ & $\mathrm{~N} / \mathrm{A}$ & $10 r-a$ & $\begin{array}{l}\text { Dagger disarm with forearm turn; note this folio } \\
\text { is in the wrong place in the Getty }\end{array}$ \\
\hline $33 r-c d$ & $12 v-b$ & $\mathrm{~N} / \mathrm{A}$ & $10 r-b$ & Dagger take-away \\
\hline $33 v-a b$ & $12 \mathrm{v}-\mathrm{c}$ & $\mathrm{N} / \mathrm{A}$ & $10 r-c$ & Counter to previous \\
\hline
\end{tabular}

72 The wear on this folio and the previous, as well as the change of subject, suggests that they were once detached from the MS, perhaps when it was rebound, and that the preceding sword section should be in a different location. This may begin a new gathering. 


\begin{tabular}{|c|c|c|c|c|}
\hline Paris & Getty 59 & Morgan & $\begin{array}{l}\text { Pisani- } \\
\text { Dossi60 }\end{array}$ & Description and Notes ${ }^{61}$ \\
\hline $33 \mathrm{v}-\mathrm{cd}$ & $15 r-d$ & $\mathrm{~N} / \mathrm{A}$ & $10 \mathrm{r}-\mathrm{e}$ & $\begin{array}{l}\text { Defense against being grabbed by a man with a } \\
\text { dagger; note the Getty illustration is not } \\
\text { crowned. This begins a section of defenses } \\
\text { against the left arm of a man grabbing you with } \\
\text { a dagger. }\end{array}$ \\
\hline $34 \mathrm{r}-\mathrm{ab}$ & $38 v-a$ & $\mathrm{~N} / \mathrm{A}$ & 10r-f & $\begin{array}{l}\text { Another defense against being grabbed by a } \\
\text { man with a dagger }\end{array}$ \\
\hline $34 \mathrm{r}-\mathrm{cd}$ & $38 v-b$ & $\bar{N} / \mathrm{A}$ & $10 v-a$ & $\begin{array}{l}\text { Defense against being grabbed by a man with a } \\
\text { dagger with double-arm smash from above }\end{array}$ \\
\hline $34 v-a b$ & $38 v-d$ & $\mathrm{~N} / \mathrm{A}$ & $10 v-b$ & $\begin{array}{l}\text { Elbow-smash defense against being grabbed by } \\
\text { a man with a dagger }\end{array}$ \\
\hline $34 \mathrm{v}-\mathrm{cd}$ & $38 \mathrm{v}-\mathrm{c}$ & $\mathrm{N} / \mathrm{A}$ & $10 v-c$ & $\begin{array}{l}\text { Leg pick-up defense against being grabbed by a } \\
\text { man with a dagger }\end{array}$ \\
\hline $35 r-a b$ & $15 r-a$ & $\mathrm{~N} / \mathrm{A}$ & $10 v-d$ & $\begin{array}{l}\text { Left arm break over the shoulder against being } \\
\text { grabbed by a man with a dagger }\end{array}$ \\
\hline $35 \mathrm{r}-\mathrm{cd}$ & $15 r-b$ & $\mathrm{~N} / \mathrm{A}$ & $10 v-e$ & Takedown against a man with a dagger \\
\hline $35 v-a b$ & $15 r-c$ & $\mathrm{~N} / \mathrm{A}$ & $10 v-f$ & Another takedown against a man with a dagger \\
\hline $35 \mathrm{v}-\mathrm{cd}$ & $15 r-d$ & $\mathrm{~N} / \mathrm{A}$ & $11 \mathrm{r}-\mathrm{a}$ & $\begin{array}{l}\text { Armlock against the left arm against being } \\
\text { grabbed by a man with a dagger }\end{array}$ \\
\hline $36 r-a b$ & $15 v-b$ & $\mathrm{~N} / \mathrm{A}$ & $11 \mathrm{r}-\mathrm{c}$ & Play against a man with a dagger \\
\hline $36 \mathrm{r}-\mathrm{cd}$ & $15 \mathrm{v}-\mathrm{c}$ & $\mathrm{N} / \mathrm{A}$ & $11 \mathrm{r}-\mathrm{d}$ & Continuation of previous \\
\hline $36 v-a b$ & $16 r-a$ & $\mathrm{~N} / \mathrm{A}$ & $11 \mathrm{r}-\mathrm{e}$ & $\begin{array}{l}\text { Sixth master of the dagger. This begins a } \\
\text { section of dagger vs. dagger (parry is uncrossed } \\
\text { high) }\end{array}$ \\
\hline $36 \mathrm{v}-\mathrm{cd}$ & $17 r-a$ & $\mathrm{~N} / \mathrm{A}$ & $11 v-e$ & $\begin{array}{l}\text { Seventh master of the dagger (parry is crossed } \\
\text { high) }\end{array}$ \\
\hline $37 r-a b$ & $17 r-c$ & $\mathrm{~N} / \mathrm{A}$ & $11 \mathrm{v}-\mathrm{a}$ & $\begin{array}{l}\text { Eighth master of the dagger (parry is uncrossed } \\
\text { low). Note the PD does not show this as a } \\
\text { master. }\end{array}$ \\
\hline $37 \mathrm{r}-\mathrm{cd}$ & $\mathrm{N} / \mathrm{A}$ & $\mathrm{N} / \mathrm{A}$ & $12 r-c$ & $\begin{array}{l}\text { The Paris and PD have this master, who is not } \\
\text { in the Getty and who takes his parry crossed } \\
\text { and low }\end{array}$ \\
\hline
\end{tabular}

73 Interestingly, the author of the Paris has placed the masters first. The plays are also reordered. 


\begin{tabular}{|c|c|c|c|c|}
\hline Paris & Getty ${ }^{59}$ & Morgan & $\begin{array}{l}\text { Pisani- } \\
\text { Dossi60 }\end{array}$ & Description and Notes ${ }^{61}$ \\
\hline $37 v-a b$ & $18 \mathrm{r}-\mathrm{a}$ & $\mathrm{N} / \mathrm{A}$ & $12 \mathrm{v}-\mathrm{c}$ & $\begin{array}{l}\text { Continuation of the play of the first student of the } \\
\text { ninth dagger master (not shown in the Paris), } \\
\text { and who defends against a thrust: stab to the } \\
\text { chest }\end{array}$ \\
\hline $37 v-c d$ & $18 \mathrm{r}-\mathrm{d}$ & $\mathrm{N} / \mathrm{A}$ & $12 r-f$ & $\begin{array}{l}\text { Fourth student of the ninth dagger master: Arm } \\
\text { break over the shoulder }\end{array}$ \\
\hline $38 r-a b$ & $18 \mathrm{r}-\mathrm{c}$ & $\mathrm{N} / \mathrm{A}$ & $12 \mathrm{v}-\mathrm{a}$ & $\begin{array}{l}\text { Third student of the ninth dagger master: Turn } \\
\text { the elbow with inverted hand. This is shown as a } \\
\text { counter-master in the Paris. }\end{array}$ \\
\hline $38 \mathrm{r}-\mathrm{cd}$ & $18 \mathrm{r}-\mathrm{b}$ & $\mathrm{N} / \mathrm{A}$ & $12 \mathrm{v}-\mathrm{b}$ & $\begin{array}{l}\text { Second student of the ninth dagger master: } \\
\text { Two-arm hold. This is shown as a counter- } \\
\text { master in the Paris. }\end{array}$ \\
\hline $38 v-a$ & $6 r-a$ & $\mathrm{~N} / \mathrm{A}$ & $4 \mathrm{r}-\mathrm{a}$ & Wrestling master of posta longa \\
\hline $38 v-b$ & $6 r-b$ & $\mathrm{~N} / \mathrm{A}$ & $4 r-b$ & Wrestling master of dente di cinghiaro \\
\hline $38 v-c$ & $6 r-c$ & $\mathrm{~N} / \mathrm{A}$ & $4 \mathrm{r}-\mathrm{c}$ & Wrestling master of porta di ferro \\
\hline $38 v-d$ & $6 r-d$ & N/A & $4 r-d$ & Wrestling master of posta frontale \\
\hline $39 r-a b$ & $6 v-a$ & $\mathrm{~N} / \mathrm{A}$ & $4 \mathrm{v}-\mathrm{a}$ & $\begin{array}{l}\text { First student of wrestling: Breaking the hold. The } \\
\text { reason for the crown is unknown. }\end{array}$ \\
\hline $39 r-c d$ & $6 v-b$ & $\mathrm{~N} / \mathrm{A}$ & $4 \mathrm{v}-\mathrm{b}$ & Second student of wrestling: Arm lock \\
\hline $39 v-a b$ & $6 v-c$ & $\mathrm{~N} / \mathrm{A}$ & $4 \mathrm{v}-\mathrm{c}$ & $\begin{array}{l}\text { Third student of wrestling: Leg and collar throw. } \\
\text { The reason for the crown is unknown. }\end{array}$ \\
\hline $39 v-c d$ & $6 v-d$ & $\mathrm{~N} / \mathrm{A}$ & $4 \mathrm{v}-\mathrm{d}$ & $\begin{array}{l}\text { Fourth student of wrestling: Neck and elbow } \\
\text { throw. Note that the Getty seems to show the } \\
\text { elbow, not the waist. The reason for the crown is } \\
\text { unknown. }\end{array}$ \\
\hline $40 r-a b$ & $7 \mathrm{r}-\mathrm{a}$ & $\mathrm{N} / \mathrm{A}$ & $4 \mathrm{v}-\mathrm{e}$ & $\begin{array}{l}\text { Fifth student of wrestling: Chin and waist throw. } \\
\text { The reason why the figure is depicted as a } \\
\text { counter-master in the Paris is unknown. }\end{array}$ \\
\hline 40r-cd & $7 r-b$ & $\mathrm{~N} / \mathrm{A}$ & $4 v-f$ & Counter to previous \\
\hline $40 v-a b$ & $7 r-c$ & $\mathrm{~N} / \mathrm{A}$ & $5 r-a$ & $\begin{array}{l}\text { Sixth student of first wrestling master: Leg lift } \\
\text { with head under arm }\end{array}$ \\
\hline $40 \mathrm{v}-\mathrm{cd}$ & $7 r-d$ & $\mathrm{~N} / \mathrm{A}$ & $5 r-b$ & $\begin{array}{l}\text { Seventh student of first wrestling master: Thumb } \\
\text { under ear }\end{array}$ \\
\hline $41 \mathrm{r}-\mathrm{ab}$ & $7 v-a$ & $\mathrm{~N} / \mathrm{A}$ & $5 r-c$ & Eighth student of wrestling: Hip throw \\
\hline $41 \mathrm{r}-\mathrm{cd}$ & $7 v-b$ & $\mathrm{~N} / \mathrm{A}$ & $5 r-d$ & Ninth student of wrestling: Leg trip-up \\
\hline
\end{tabular}




\begin{tabular}{|c|c|c|c|c|}
\hline Paris & Getty ${ }^{59}$ & Morgan & $\begin{array}{l}\text { Pisani- } \\
\text { Dossi60 }\end{array}$ & Description and Notes ${ }^{61}$ \\
\hline $41 v-a b$ & $7 v-c$ & $\mathrm{~N} / \mathrm{A}$ & $5 r-e$ & Tenth student of wrestling: Full Nelson \\
\hline $41 v-c d$ & $7 v-d$ & $\mathrm{~N} / \mathrm{A}$ & $5 r-f$ & Eleventh student of wrestling: Knee to groin \\
\hline $42 r-a b$ & $8 r-a$ & $\mathrm{~N} / \mathrm{A}$ & $5 \mathrm{v}-\mathrm{a}$ & Twelfth student of wrestling: Hit to nose/face \\
\hline $42 r-c d$ & $8 r-b$ & N/A & $5 \mathrm{v}-\mathrm{b}$ & Thirteenth student of wrestling: Leg pick-up \\
\hline $42 v-a b$ & $8 r-c$ & $\bar{N} / \mathrm{A}$ & $5 v-c$ & $\begin{array}{l}\text { Fourteenth student of wrestling: Push against } \\
\text { the face }\end{array}$ \\
\hline $42 v-c d$ & $8 r-d$ & $\mathrm{~N} / \mathrm{A}$ & $5 v-d$ & $\begin{array}{l}\text { Counter to fourteenth student of wrestling; note } \\
\text { the figure in the Paris is not shown as a counter- } \\
\text { master }\end{array}$ \\
\hline $43 r-a b$ & $18 v-a$ & $\mathrm{~N} / \mathrm{A}$ & $12 v-e$ & $\begin{array}{l}\text { Dagger defense: Continuation of first student of } \\
\text { ninth master (dagger between the legs) }{ }^{74}\end{array}$ \\
\hline $43 r-c d$ & $11 v-b$ & $\mathrm{~N} / \mathrm{A}$ & $12 r-b$ & Counter to the first dagger master \\
\hline $43 v-a b$ & $10 v-b$ & $\mathrm{~N} / \mathrm{A}$ & $8 r-a$ & $\begin{array}{l}\text { Another counter to the first dagger master. Note } \\
\text { that the PD does not show this as a counter- } \\
\text { master, though it is called such in the text. }\end{array}$ \\
\hline $43 \mathrm{v}-\mathrm{cd}$ & $11 \mathrm{v}-\mathrm{c}$ & $\mathrm{N} / \mathrm{A}$ & $8 r-c$ & Another counter to the first dagger master \\
\hline $44 \mathrm{r}-\mathrm{ab}$ & $11 v-a$ & $\mathrm{~N} / \mathrm{A}$ & $\mathrm{N} / \mathrm{A}$ & Another counter to the first dagger master \\
\hline $44 r-c d$ & $\mathrm{~N} / \mathrm{A}$ & $\mathrm{N} / \mathrm{A}$ & $\mathrm{N} / \mathrm{A}$ & The epitaph is unique to MS 11269 \\
\hline
\end{tabular}

74 The return to dagger counters in the Paris is intriguing: One possibility is that the page was misplaced in rebinding, but the epitaph in the same hand as the rest of the text would seem to argue against this. It is also interesting to note that the author of the Paris seems to have moved counters to the ends of the various sections. 